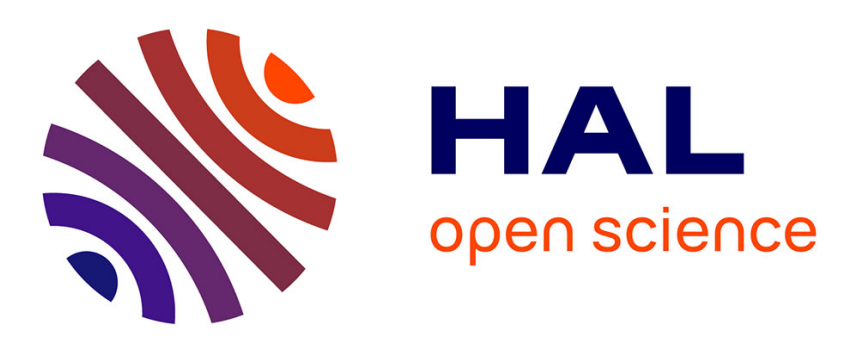

\title{
Building models of Neanderthal territories from raw material transports in the Aquitaine Basin (southwestern France)
}

Alain Turq, Jean-Philippe Faivre, Brad Gravina, Laurence Bourguignon

\section{To cite this version:}

Alain Turq, Jean-Philippe Faivre, Brad Gravina, Laurence Bourguignon. Building models of Neanderthal territories from raw material transports in the Aquitaine Basin (southwestern France). Quaternary International, 2017, 433, pp.88-101. 10.1016/j.quaint.2016.02.062 . hal-03032364

\section{HAL Id: hal-03032364 https://hal.science/hal-03032364}

Submitted on 30 Nov 2020

HAL is a multi-disciplinary open access archive for the deposit and dissemination of scientific research documents, whether they are published or not. The documents may come from teaching and research institutions in France or abroad, or from public or private research centers.
L'archive ouverte pluridisciplinaire HAL, est destinée au dépôt et à la diffusion de documents scientifiques de niveau recherche, publiés ou non, émanant des établissements d'enseignement et de recherche français ou étrangers, des laboratoires publics ou privés. 


\title{
Building models of Neanderthal territories from raw material transports in the Aquitaine Basin (southwestern France)
}

\author{
Alain Turq, J ean-Philippe Faivre, Brad Gravina, Laurence Bourguignon
}

Keywords:

Raw material Mobility

patterns Middle

Palaeolithic

Petroarcheology

Southwestern France

Techno-economy

\begin{abstract}
a b s t r a c t
The Middle Palaeolithic of southwestern France has long been a testing ground for models of Nean- derthal lithic assemblage variability and mobility strategies. Advances in our understanding of the lithological structure of the northern Aquitaine Basin combined with numerous raw material studies allows connections between different areas of the region to be revealed based on the movement of particular 'tracer' materials. By comparing technological data with raw material transport patterns ele- ments of Late Neanderthal techno-economic behaviour emerge. Raw materials were transferred over longer distances in both the Levallois and Quina techno-complexes compared to the Discoid techno-complexes, where evidence for similar movements are almost entirely absent. Comparing these patterns of raw material provisioning and transfer against the distribution of key Middle Palaeolithic sites forms the basis of a new model for the territorial organisation of Late Neandertal groups in the Aquitaine Basin to be built.
\end{abstract}

\section{Introduction}

The northeast of the Aquitaine Basin has produced numerous Middle Palaeolithic sites and presents considerable diversity in terms of ecosystems and varieties of lithic raw materials. Several recent studies focusing on the relationship between raw materials and stone tool technology have shed new light on the territorial organisation of Neanderthal groups (e.g. Turq et al., 2013a,b). Additionally, the last thirty years have seen the growth of a naturalist approach to the geological and geographical characterisation of raw materials from across southwestern France (Demars, 1980; Morala, 1980, 1983; Rigaud, 1982; Geneste, 1985) with the aim of better understanding the organisation of Palaeolithic hunter-gatherer groups within the territories they exploited. This data moves interpretations of Neanderthal mobility patterns beyond traditional definitions of subsistence territories connected to particular occupation types, allowing both relationships within and between territories to be explored. This type of analysis requires defining specific lithological zones (hereafter LZ) whose geological formations contain specific raw materials. Any given territory includes one or several LZ that contain evidence for the movement of raw materials in all stages of the chaîne opératoire, including blank production, bifacial shaping as well as tool manufacture and use.

This techno-economic approach is based not only on the continued revision of Mousterian lithic techno-complexes (e.g. Delagnes et al., 2007; Turq et al., 2011; Jaubert, 2011; Faivre, 2011, 2014, in press; Gravina and Discmaps, 2015) but also traditional models of huntergatherer mobility systems (e.g. Binford and Binford, 1969; Binford, 1979; Kuhn, 1992, 1995; Andrefsky, 2009). Raw material analysis combined with a consideration of techno-economic patterns builds upon and refines previous models of Neanderthal mobility strategies based on blank production systems and bifacial shaping (e.g. Delagnes, 2010; Delagnes and Rendu, 2011). The development of rescue archaeology over the last two decades has produced an important number of open-air sites, which, when coupled with the revision of key sequences from both rock shelter and cave sites and methodological advances in absolute dating techniques (Guibert et al., 2008; Vieillevigne et al., 2008), provide important contextual data for reconstructing patterns of Neanderthal land-use and raw material transport patterns. 


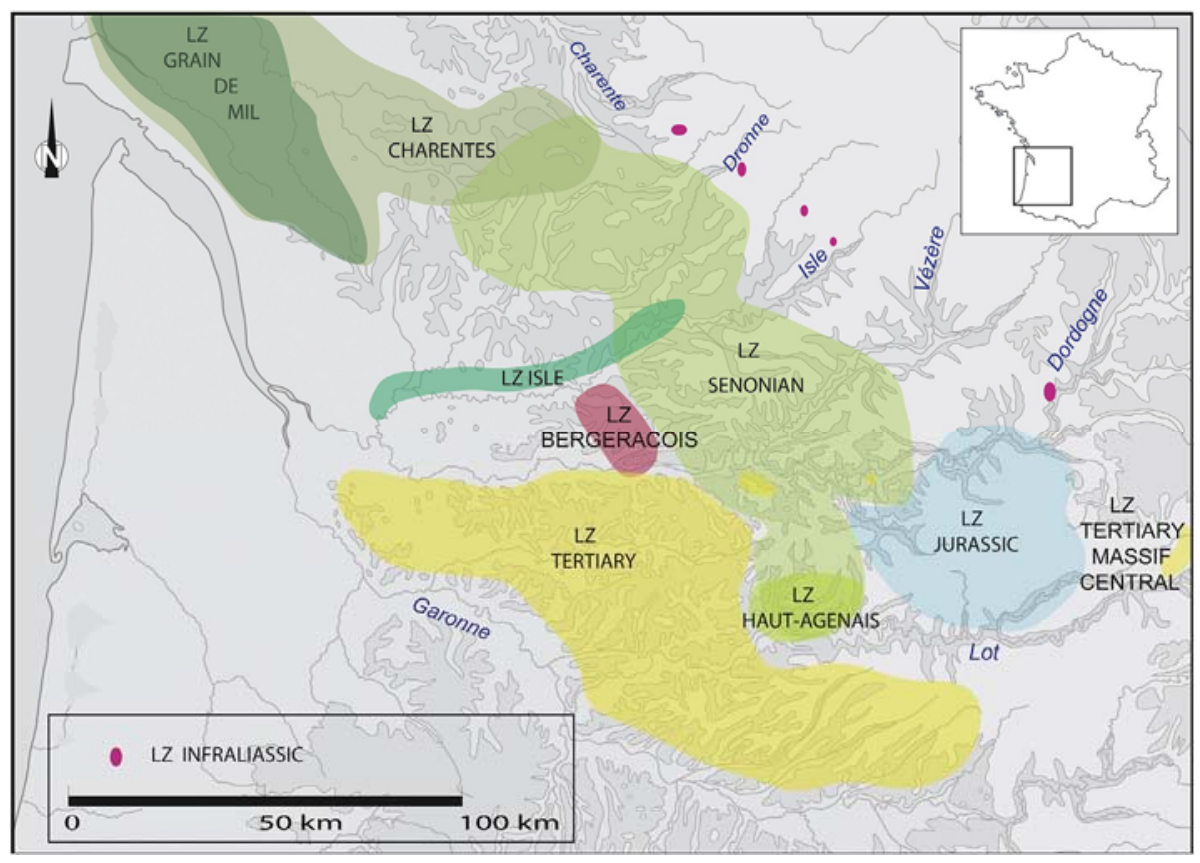

Fig. 1. Different lithological zones (LZ).

\section{Material and methods}

\subsection{Study area and definition of lithological zones (LZ)}

Here we focus on the Middle Palaeolithic occupation of the northern Aquitaine Basin from the Garonne Valley in the south to the limits of Poitou in the north (Fig. 1). The region's concentric geological structure creates a mosaic of different ecosystems containing diverse lithological zones cut by the drainage basins of the
Garonne (right bank), Lot, Dordogne, Isle and Charente Rivers. We applied well-established lithological methods (Demars, 1980; Morala, 1980, 1983; Séronie-Vivien, 1987; Turq, 1992a,b) to define raw materials characteristic of each LZ, including the morphology of the blocks (e.g. irregular nodules, lenses, small slabs), macro- (e.g. texture, cortex, couleur, granulometry) and microscopic observations (e.g. microfossils). The depositional context and post-genetic patterns of alteration (Fernandes, 2012) were equally taken into account for these 'tracer' materials.

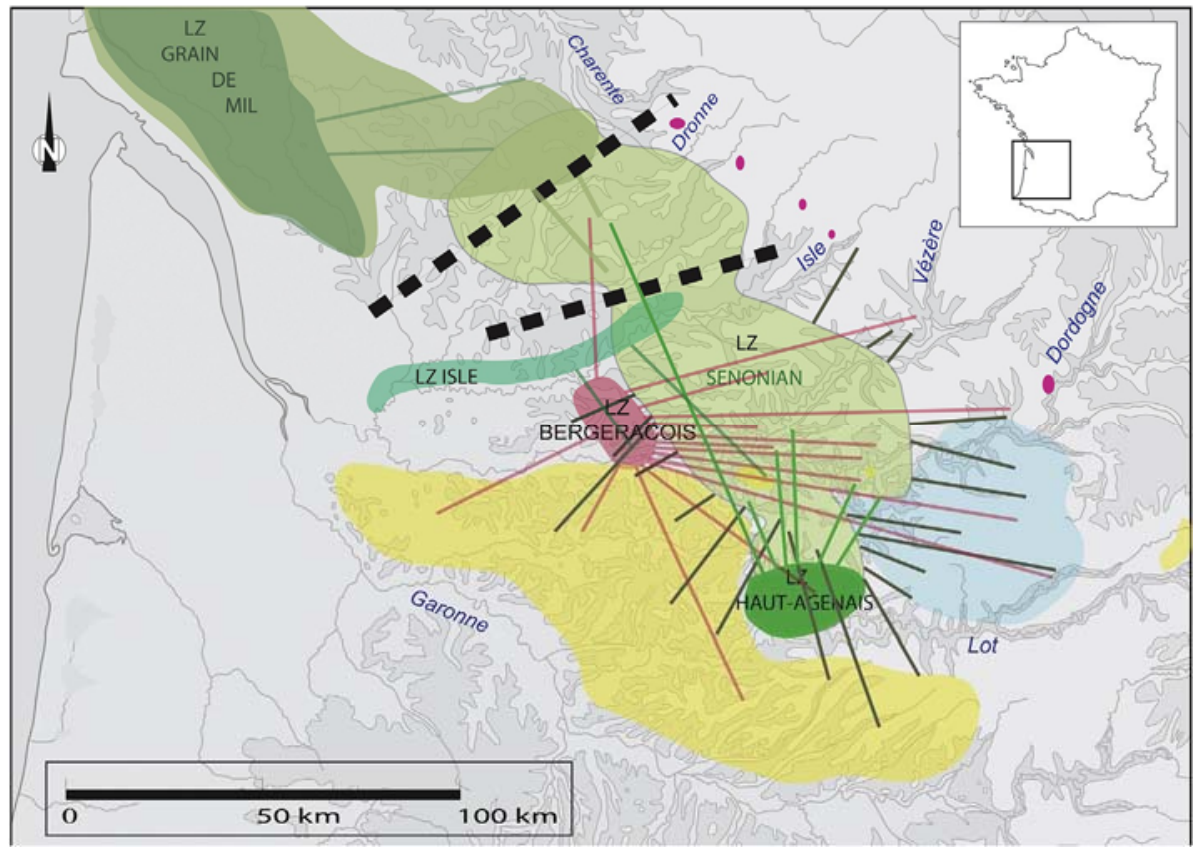

Fig. 2. Connections between different lithological zones. The red lines indicate an intermediary region where raw material from the south and north has been recovered. This region separates the Charentes from the study area to the south, where connections between different lithological zone are numerous. (For interpretation of the references to colour in this figure, the reader is referred to the web version of this article.) 


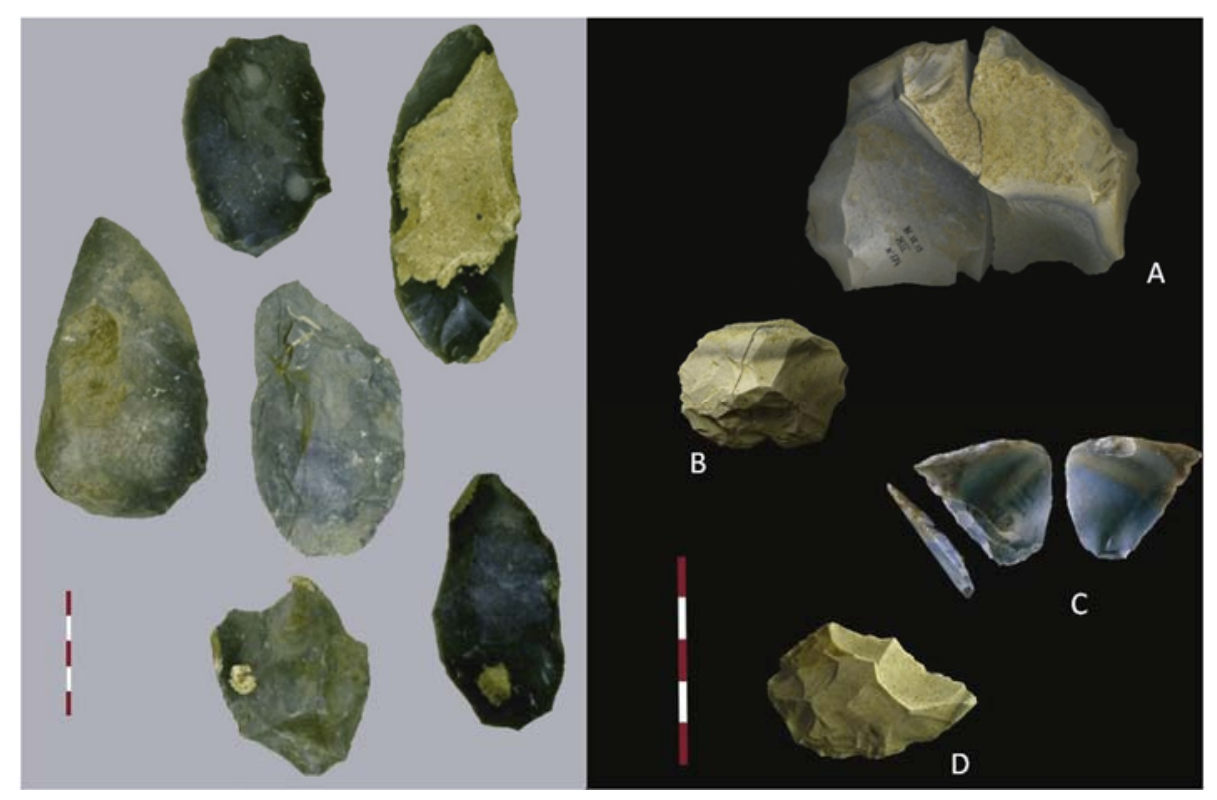

Fig. 3. Discard state of flint from two neighbouring lithological zones: Senonian flint from open-air sites in the Périgord (left), Bergeracois flint from enclosed sites in the Périgord (right). Large flake (A), scraper retouch flakes (B), scraper on a bifacial-thinning flake (C), functional tool capable of producing flakes. Photos e Philippe J ugie, Musé national de la Préhistoire.

Based on these criteria it is possible to discern $11 \mathrm{LZ}$ within the northern Aquitaine Basin (See Table 1 and Fig. 1 for their principle characteristics and geographic extension, respectively). The Infraliassic LZ appears as sporadic sources along the northern limits, with the Jurassic and Cenozoic Massif Central LZ to the east. The most extensive Senonian LZ comprises the Charentes and over-lapping 'grain de mil' $\mathrm{LZ}$ to the north of the more central Perigord Senonian, Isle, and Bergeracois LZ. Finally, the Haut Agenais LZ, formed by the Fumelois and Gavaudan flints, and the Tertiary LZ lie to the south. The geography of these lithological 'tracers' and the organisation of the hydrographical network make it impossible to document the westeeast movement of raw materials to the east of Bergerac. Additionally, tracing the circulation of raw materials in the west is complicated by the fact that eastern materials can be collected downstream in alluvial deposits across the Aquitaine Basin. Therefore, only pieces with non-alluvial cortex were considered, meaning that jaspers, Cenozoic flint from the Massif Central and Jurassic flints are absent or underrepresented. On-going work concerning the postgenetic alteration of these raw materials (Fernandes, 2012) will hopefully provide more reliable information in terms of their acquisition and transport.

\section{Material and methods}

The analysed collections primarily come from recently excavated sites, including rescue excavations (see Table 2). In order to include the maximum amount of relevant data for establishing connections between the different LZ, we integrated data from the archaeological mapping project of the French Ministry of Culture (Reseau nationale des lithotheques) as well as lithological data compiled from surface collections and isolated pieces in public and private collections. Although these latter pieces lack reliable contextual information, their degree of patination compared to examples from secure MIS 6 contexts and their conforming to the techno-typological characteristics of the so-called "MTA" bifaces (Boëda et al., 1990, 2005, 2013; Soressi, 2002) nevertheless strongly suggest their dating to MIS $5 \mathrm{e} 3$.

Our techno-economic approach takes into account the most recent advances in both technological and lithological analysis, including integrating genetic and post-genetic phenomenon (Turq, 2004; Fernandes, 2012) that go beyond simply determining flint type. In certain cases not only can the type of source beidentified (e.g.primary, secondary, alluvial) but also the minimum number of exploited blocks (Turq et al., 2013a,b). Finally, bearing in mind the ramified nature of certain reduction systems (Bourguignon et al., 2004) as well as the identifiable waste products from the manufacture and maintenance of certain tools (Bourguignon, 1992, 1997, 2001; Bourguignon et al., 2013), we also examined the small fraction from more recent excavations. These elements are rarely if ever included in most lithic analyses.

\section{Results}

Unlike the situation further north, the rarity of archaeological sites towards the northern limits of the Aquitaine Basin (see above) likely reflect unfavourable ecological conditions of the Massif Central, including the expansion of the Cantal ice sheet during cold periods. Similarly, the mollasic formations of the Dropt and Lot valleys in the southern area likely explains the low density of sites in this area (Le Tensorer, 1979; Le Brun Ricalens, 1988), while substantial aeolian deposits in the Garonne Valley probably led human groups to desert the area (Bruxelles and Jarry, 2011; Bertran et al., 2013; Sitzia, 2014). Finally, the Atlantic Coast, whose position var- ied according to fluctuating sea levels, represents the western limit of the basin (Fig. 2).

In order to avoid using arbitrary geographic limits, discontinuities in connections between lithological zones (LZ) provide a more reliable indicator of different territories (Table 2). Objects from southern LZ are never found in the Charentes and become increasingly rare north of Périgueux, whereas Charentian materials do not move beyond the Dronne Valley. Transfers from the south and north go no further than the area around Bourdeilles or 
Table 1 - Comparison of theorigin of rawmaterials and archaeological data. Colors correspond to the broad lithological zones, apart from the brown for the Charentes. Infralias (violet), J urassic (blue), Cretaceous (green), Cenozoic (yellow), Metaquartzites (white). D indicates the dominant raw material, $\mathrm{X}$ securely identified materials, $\mathrm{x}$ probable raw materials as their acquisition from alluvial deposits cannot be ruled out. In addition to the list of studied assemblages can be found a synthesis of 6000 bifaces held in different private and public collections; Mussénational de Préhistoire des Eyzies, Musée des Antiquités Nationale de Saint-Germain-en-Laye, Musée d'Aquitaine in Bordeaux, Musée du Périgord in Périgueux, musée Labenche in Brive, Musée A. Lemozi in Cabrerets et the museums of Agen, Montauban, Cahors, Agen and Sainte Bazeille (Bernard-Guelle et al., 2014, Bordes, 2002, Bruxelles etal., 2010, Cassedoubat and Platel, 1976, Caux, 2015, Cavaillé 1978, Chadelle, 1983, Chalard, 1996, Chalard, 1999, Charly, 1993, Combaz, 1966, Sonneville-Bondes, 1953, Turq 1977, Turq, 1988, Turq, 1990b, Vergne, 1929, Weyns, 1972, Dawson et al., 2012, F'́blot-Augustins et al., 2005, Féblot-Augustions and Park, 2009, Fernandes et al., 2012, Fouéé, 1994, Landesque, 1887, Larick, 1983, Lorblanchet, 1969, Monméjean et al., 1964, Muratet, 1983, Park, 2007, Pasty et al., 1999, Rey-Soléet al., 2014, Roussel, 1972, Simon-Coinģon, 1989;

Coulonges and Sonneville-Bordes, 1953; Cubaynes et al, 1989).

\begin{tabular}{|c|c|c|c|c|}
\hline DESIGNATION & TYPE & $\begin{array}{l}\text { GEOLOGICAL } \\
\text { FORMATION }\end{array}$ & CHARACTERISTICS & REFERENCES \\
\hline Massif Central & Flint & $\begin{array}{l}\text { Lacustrine Tertiary } \\
\text { (Oligocene) }\end{array}$ & $\begin{array}{l}\text { Texture : mudstone to wackestone } \\
\text { Colour : grey-beige with blue and } \\
\text { pink green tones, } \\
\text { Paleonto. : fresh water flora and } \\
\text { fauna (Gastropodes, Characeae) }\end{array}$ & $\begin{array}{l}\text { Muratet 1983; Simon-Coinçon } \\
\text { 1989; Turq 1992; Charly 1993; } \\
\text { Pasty et al 1999; Turq and Morala } \\
2013\end{array}$ \\
\hline Aquitaine Basin & $\begin{array}{l}\text { Chalcedonous } \\
\text { flint } \\
\text { Chalcedony } \\
\text { Gritstone }\end{array}$ & Lacustrine Tertiary & $\begin{array}{l}\text { Texture : mudstone } \\
\text { Colour : beige } \\
\text { Paleonto. : when present } \\
\text { Characeae, Gastropodes }\end{array}$ & $\begin{array}{l}\text { Demars 1980; Morala 1980. ; } \\
\text { Chadelle J.-P. 1983, Larick 1983; } \\
\text { Geneste 1985; Lebrun-Ricalens } \\
1988 \text {;Turq 1992; Turq and Morala } \\
2013 .\end{array}$ \\
\hline Bergeracois & Flint & $\begin{array}{l}\text { Maestrichtian } \\
\text { (Campanian } 4-5 \\
\text { Paleogene epigenesis) }\end{array}$ & $\begin{array}{l}\text { Texture : mudstone to wackestone } \\
\text { Colour : initially brown, beige or grey, } \\
\text { uniform or with red,orange or blueish } \\
\text { zonation } \\
\text { Paleento. : Orbitoides media.... }\end{array}$ & $\begin{array}{l}\text { Landesque 1887; Combaz } 1966 \text {; } \\
\text { Demars } 1980 \text {; Morala } 1980 \text {; Larick } \\
\text { 1983; Geneste } 1985 \text {; Turq } 1992 \text {; } \\
\text { Turq and Morala } 2013\end{array}$ \\
\hline Charentian Cretaceous & Flint & $\begin{array}{l}\text { Senonian and } \\
\text { Turonian }\end{array}$ & $\begin{array}{l}\text { Texture : mudstone to wackestone or } \\
\text { packstone } \\
\text { Colour : black or grey } \\
\text { Paleento. : incertae sedis, Bryozoa, }\end{array}$ & \multirow{2}{*}{$\begin{array}{l}\text { Seronie-Vivien 1987, Fouéré } 1994 \text {, } \\
\text { Bordes 2002, Feblots Augustin and } \\
\text { al. 2005, 2009, Park 2007, } \\
\text { Fernandez 2012, Dawson et al. } \\
\text { 2012, Bernard Guelle et al. } 2014 \text {, } \\
\text { Rey Sola et al. 2014, Caux } 2015\end{array}$} \\
\hline$\&$ Grain de mil" & Flint & Senonian (Santonian) & $\begin{array}{l}\text { Texture : wackestone or packstone } \\
\text { Colour : blond to grey or black } \\
\text { Paleento. : bioclastes, Bryozoa }\end{array}$ & \\
\hline $\begin{array}{l}\text { Grey and black Périgord } \\
\text { Senonian }\end{array}$ & Flint & $\begin{array}{l}\text { Senonian (Coniacian, Santonian } \\
\text { and Campanian) }\end{array}$ & $\begin{array}{l}\text { Texture : mudstone to wackestone, or } \\
\text { packstone } \\
\text { Colour : grey or black } \\
\text { Paleento. : Bryozoa, Foraminifera } \\
\text { (Nummofallotia).... }\end{array}$ & \multirow{4}{*}{$\begin{array}{l}\text { Roussel 1972, Demars 1980, } \\
\text { Morala 1980, Rigaud 1982, Larick } \\
\text { 1983, Geneste } 1985\end{array}$} \\
\hline $\begin{array}{l}\text { Blond and brown Périgord } \\
\text { Senonian }\end{array}$ & Flint & $\begin{array}{l}\text { Senonian (Coniacian, } \\
\text { Santonian and Campanian) }\end{array}$ & $\begin{array}{l}\text { Texture : mudstone to wackestone or } \\
\text { packstone } \\
\text { Colour : light to dark brown } \\
\text { Paleento. : Bryozoa, Foraminifera } \\
\text { (Nummofallotia) }\end{array}$ & \\
\hline Pseudo-Gavaudun or Truffel & Flint & $\begin{array}{l}\text { Upper Santonian } \\
\text { to Lower Campanian } \\
\text { (Paleogene epigenesis) }\end{array}$ & $\begin{array}{l}\text { Texture : mudstone to wackestone } \\
\text { Colour : beige, brun-beige, } \\
\text { Paleento. : Bryozoa, Foraminifera } \\
\text { (Nummofallotia), miliolidae }\end{array}$ & \\
\hline Belves & Flint & Lower Campanian & $\begin{array}{l}\text { Texture : mudstone } \\
\text { Colour : grey to dark grey and black } \\
\text { Paleento. : Foraminifera } \\
\text { (Subalvéolina dordonica major, } \\
\text { Orbitoides tissoti) }\end{array}$ & \\
\hline Gavaudun & Flint & Lower Coniacian & $\begin{array}{l}\text { Texture : mudstone } \\
\text { Colour : light beige } \\
\text { Paleento.: Bryozoa }\end{array}$ & $\begin{array}{l}\text { Vergnes } 1929 \text {; Monméjean et al. } \\
1964 \text {; Bordes } 1964 \text {; Le Tensorer } \\
1979 ; \text { Morala } 1980,1982 \text {; Séronie- } \\
\text { Vivien } 1987 \text {; Turq 1992; Turq and } \\
\text { Morala } 2013\end{array}$ \\
\hline Fumélois & Flint & Lower Turonian & $\begin{array}{l}\text { Texture : mudstone } \\
\text { Colour : dark blue, uniform or zoned } \\
\text { honey brown or black } \\
\text { Paleento. : Bryozoa, Annelida }\end{array}$ & $\begin{array}{l}\text { Sonneville-Bordes 1953; Coulonges } \\
\text { and Sonneville-Bordes 1953; } \\
\text { Monméjean et al. 1964; Weyns } \\
\text { 1972; Turq 1977a; Le Tensorer } \\
\text { 1979; Morala 1980; Rigaud 1982; } \\
\text { Chadelle 1983; Larick 1983; Morala } \\
\text { 1983 and 1990; Cassoudebat-Platel } \\
\text { 1976; Geneste 1985; Séronie- } \\
\text { Vivien 1987; Turq 1992; Turq and } \\
\text { Morala 2013 }\end{array}$ \\
\hline Missère & Flint & $\begin{array}{l}\text { Tithonian } \\
\text { (Purbeckian) }\end{array}$ & $\begin{array}{l}\text { Texture : mudstone, veritical tubes } \\
\text { Colour : beige, brown, greenish,... } \\
\text { Paleento. : (not specified) }\end{array}$ & \multirow{3}{*}{$\begin{array}{l}\text { Lorblanchet 1969, Cavaillé } 1978 \text {, } \\
\text { Demars, 1980, Séronie-Vivien } \\
1987, \text { Cubaynes and al. 1989, Turq } \\
\text { 1990, 1992, Chalard 1996, 1999, } \\
\text { Bruxelles and al. 2010, Turq and } \\
\text { Morala 2013 }\end{array}$} \\
\hline Dogger & Flint & $\begin{array}{l}\text { Aalenian, Bajocian } \\
\text { and Bathonian }\end{array}$ & $\begin{array}{l}\text { Texture : mudstone, packstone or } \\
\text { grainstone (oolithic) } \\
\text { Colour : grey or beige with yellow- } \\
\text { orange zonation and red filaments } \\
\text { Paleento. : marine (Foraminifera) and } \\
\text { lacustrine (Characeae) to Bathonian, }\end{array}$ & \\
\hline Lias Moyen & Flint & $\begin{array}{l}\text { Carixian, Domerian } \\
\text { (Pleinsbachian) }\end{array}$ & $\begin{array}{l}\text { Texture : mudstone, wackerstone, } \\
\text { Colour : beige, brown, grey, more } \\
\text { rarely greyish black } \\
\text { Paleento. : large canicular spicules }\end{array}$ & \\
\hline Infralias & Jasper & $\begin{array}{l}\text { Hettangian and } \\
\text { Sinemurian (epigenesis) }\end{array}$ & $\begin{array}{l}\text { Texture : mudstone, wackerstone, } \\
\text { packstone (oolithic) } \\
\text { Colour : mustard yellow, greenish, } \\
\text { brown, manganese spots or dendrites } \\
\text { (brown-black) } \\
\text { Paleento.: shell fragments }\end{array}$ & $\begin{array}{l}\text { Demars 1980, Bordes 2002, } \\
\text { Geneste 1985; Turq 1992; Turq and } \\
\text { Morala 2013 }\end{array}$ \\
\hline
\end{tabular}


Table 2

Comparison of lithic techno-complexes with the origins of raw material as well as the archaeological data. The legend is the same as Table 1.

\begin{tabular}{|c|c|c|c|c|c|c|c|c|c|c|c|c|c|c|c|c|c|}
\hline & & & & 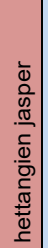 & 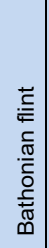 & 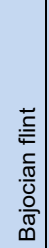 & 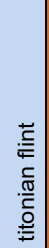 & 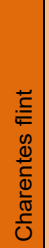 & 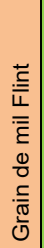 & 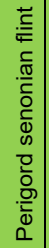 & 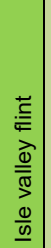 & 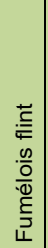 & 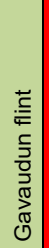 & $\begin{array}{l}\vec{c} \\
\stackrel{c}{6} \\
\frac{\infty}{0} \\
0 \\
\frac{\pi}{0} \\
\overline{0} \\
\frac{0}{0} \\
\infty\end{array}$ & 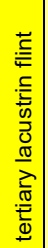 & 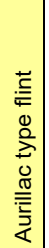 & 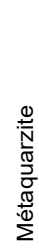 \\
\hline Lithological Zones (LZ) & Studied sites & $\mathrm{N}^{\circ}$ fig.6 & type & & & & & & & & & & & & & & \\
\hline \multirow{6}{*}{ Bergeracois } & Combe Brune 1 & 1 & $\mathrm{O}$ & & & $\mathbf{X}$ & & & & $\mathbf{X}$ & $\mathbf{x}$ & & & $\mathbf{D}$ & $\mathbf{X}$ & & \\
\hline & Toutifaut & 2 & 0 & & & & & & & $\mathbf{X}$ & & & & D & $\mathbf{X}$ & & \\
\hline & Corbiac & 3 & $\mathrm{O}$ & & & & & & & $\mathbf{x}$ & & & & D & $\mathbf{X}$ & & \\
\hline & \begin{tabular}{|l} 
Vieux cloutet \\
\end{tabular} & 4 & $\mathrm{O}$ & & & & & & & $\mathbf{x}$ & & & & D & $\mathbf{X}$ & & \\
\hline & Bois des vergnes & 5 & $\mathrm{O}$ & & & & & & & $\mathbf{X}$ & & & & D & $\mathbf{X}$ & & \\
\hline & BIFACES & & & & & & & & & $\mathbf{X}$ & & & & D & $\mathbf{x}$ & & \\
\hline \multirow{8}{*}{ Haut Agenais } & Sous les Vignes & 6 & $\mathrm{O}$ & & & & & & & D & & $\mathbf{X}$ & $\mathbf{X}$ & & $\mathbf{X}$ & $\mathrm{x}$ & $\mathbf{X}$ \\
\hline & \begin{tabular}{|l|} 
Las Pelenos \\
\end{tabular} & 7 & $E$ & & & & & & & D & & $\mathbf{X}$ & $\mathbf{X}$ & & $\mathbf{X}$ & $\mathrm{x}$ & $\mathbf{x}$ \\
\hline & Moulin du Milieu & 8 & $\mathrm{E}$ & & & & & & & $\mathbf{X}$ & & $\mathbf{X}$ & D & & & $\mathrm{x}$ & \\
\hline & Las Planes & 9 & $\mathrm{O}$ & & & & & & & $\mathbf{x}$ & & & & & $\mathbf{x}$ & & D \\
\hline & La Pronquière & 10 & $E$ & & & & & & & $\mathbf{X}$ & & & & & & & D \\
\hline & Cassegros & 11 & $\mathrm{E}$ & & & & & & & $\mathbf{X}$ & & & & & & & D \\
\hline & \begin{tabular}{|l|} 
Les Ardailloux \\
\end{tabular} & 12 & $\mathrm{O}$ & & & & & & & D & & & & 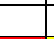 & & & \\
\hline & BIFACES & & & & & & & & & D & & & & $\mathrm{x}$ & $\mathbf{x}$ & & \\
\hline \multirow{4}{*}{ Périgord sud } & La Plane & 13 & $\mathrm{O}$ & $x$ & & $\mathbf{x}$ & $\mathbf{x}$ & & & D & & $\mathbf{x}$ & & $\mathrm{x}$ & $\mathbf{x}$ & & $\mathrm{x}$ \\
\hline & Combe capelle & 14 & $E$ & & & & & & & D & & $\mathbf{X}$ & $\mathbf{x}$ & & & & \\
\hline & Combe Capelle bas & 15 & $\mathrm{O}$ & & & & & & & $\mathbf{D}$ & & $\mathbf{X}$ & $\mathbf{X}$ & 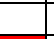 & & & \\
\hline & BIFACES & & & & & & & & & D & & & & $x$ & & & \\
\hline \multirow{14}{*}{$\begin{array}{l}\text { Périgord central } \\
\text { ou Périgord noir }\end{array}$} & Roc de Marsal & 16 & $E$ & $x$ & & & & & & D & & $\mathbf{x}$ & & $x$ & $\mathbf{x}$ & & $\mathrm{x}$ \\
\hline & Pech de l'azé 1 & 17 & $E$ & $x$ & & & & & & D & & & & $x$ & $x$ & & $x$ \\
\hline & Pech de l'azé IV & 18 & $E$ & $x$ & & & & & & D & & & & $x$ & $x$ & & $x$ \\
\hline & Grotte XVI & 19 & $E$ & & & & & & & D & & & & $x$ & $\mathbf{x}$ & & $x$ \\
\hline & Combe grenal & 20 & $E$ & $x$ & & & $x$ & & & D & & $x$ & & $x$ & $x$ & $x$ & $x$ \\
\hline & Roc de Combe & 21 & $E$ & & & & & & & D & & & & 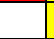 & $x$ & & $x$ \\
\hline & Le Moustier & 22 & $E$ & & & & & & & D & & & & $x$ & $x$ & & $x$ \\
\hline & La Rochette & 23 & $E$ & & & & & & & D & & & & $x$ & $\mathbf{x}$ & & $\mathbf{x}$ \\
\hline & La Gane & 24 & $\mathrm{E}$ & $x$ & & & & & & D & & $\mathbf{x}$ & & $x$ & $\mathbf{x}$ & & $\mathbf{x}$ \\
\hline & Pech de Bourre & 25 & $E$ & $x$ & & $x$ & & & & D & & $\mathbf{x}$ & & $x$ & $\mathbf{x}$ & & $\mathbf{x}$ \\
\hline & La Ferrassie petit abri & 26 & $E$ & & & & & & & D & & & & $x$ & & & $\mathbf{x}$ \\
\hline & Vaufrey & 27 & $\mathrm{E}$ & & & & & & & D & & & & $x$ & & & $\mathbf{x}$ \\
\hline & La Ferrassie grand abri & 28 & $\mathrm{E}$ & $x$ & & & & & & D & & & & $x$ & & & $\mathbf{x}$ \\
\hline & BIFACES & & & & & & & & & D & $x$ & & & $\mathrm{x}$ & & & $\mathrm{x}$ \\
\hline \multirow{4}{*}{$\begin{array}{l}\text { Périgord } \\
\text { nord }\end{array}$} & Les Festons & & $E$ & & & & & & & D & & & & & & & \\
\hline & Tabaterie & & $\mathrm{E}$ & & & & & & & D & & & $\mathbf{x}$ & & & & \\
\hline & Fonseigner & & $E$ & $x$ & & & & & & D & & & & $\mathrm{x}$ & $\mathbf{x}$ & & $\mathbf{x}$ \\
\hline & Le Roc & & $\mathrm{O}$ & $x$ & & & & & & D & & & & 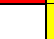 & $x$ & & \\
\hline \multirow{5}{*}{$\begin{array}{l}\text { Formation } \\
\text { molassique }\end{array}$} & Chemin d'herbes & 29 & $\mathrm{O}$ & & & & & & & $\mathbf{x}$ & & & & 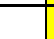 & $\mathbf{D}$ & & $\mathbf{x}$ \\
\hline & Estelet bulit & 30 & $\mathrm{O}$ & & & & & & & $\mathrm{x}$ & & & & $x$ & D & & $\mathbf{x}$ \\
\hline & Chinchon & 31 & $\mathrm{O}$ & & & & & & & $\mathrm{x}$ & & & & $x$ & D & & \\
\hline & Soumensac & 32 & $\mathrm{O}$ & & & & & & & $\mathbf{x}$ & & & & $\mathrm{x}$ & D & & $\mathbf{x}$ \\
\hline & BIFACES & & & & & & & & & $\mathrm{x}$ & & & & $x$ & D & & \\
\hline \multirow{5}{*}{ Quercy } & Mas Viel & 33 & $E$ & & $\mathbf{x}$ & $\mathbf{x}$ & & & & $\mathbf{x}$ & & & & $\mathrm{x}$ & $x$ & & D \\
\hline & Les Fieux & 34 & $E$ & & $\mathbf{x}$ & $x$ & & & & $x$ & & & & & $x$ & & D \\
\hline & Pradayrol & 35 & $E$ & & $\mathbf{x}$ & $x$ & & & & $\mathrm{x}$ & & & & & $x$ & & D \\
\hline & Le Pech & 36 & $\mathrm{O}$ & & & D & & & & $\mathrm{x}$ & & & & & $x$ & $x$ & \\
\hline & BIFACES & & & & & & & & & D & & & & & & & $\mathbf{x}$ \\
\hline \multirow{7}{*}{ Charentes } & \begin{tabular}{|l} 
La Quina \\
\end{tabular} & & $E$ & & & & & $\mathrm{D}$ & & & & & & & & & \\
\hline & Les Pradelles & & $E$ & & & D & & $\mathbf{X}$ & & $\mathrm{X}$ & & & & & & & \\
\hline & Artenac & & $\mathrm{E}$ & & & & & D & & & & & & & & & \\
\hline & Montmorillon & & $\mathrm{O}$ & & & & & D & & & & & & & & & \\
\hline & Dirac & & 0 & & & & & D & & & & & & & & & \\
\hline & bourgeois delaunay & & $E$ & & & & & D & & & & & & & & & $\mathrm{x}$ \\
\hline & Abri Suard & & $E$ & & & & & D & & & & & & & & & $\mathbf{x}$ \\
\hline \multirow{5}{*}{ Bassin de Brive } & Bouffia bonneval & & $E$ & & & $\mathbf{x}$ & & & & $x$ & & & & & $\mathbf{x}$ & $x$ & D \\
\hline & Bouffia 118 & & $E$ & & & $x$ & & & & $x$ & & & & & $x$ & & D \\
\hline & Chez Pourré-Chez Comte & & $E$ & & & $x$ & & & & $\mathrm{x}$ & & & & & $\mathbf{x}$ & $x$ & D \\
\hline & Combe brune & & $\mathrm{O}$ & & & & & & & $\mathrm{x}$ & & & & & $\mathbf{x}$ & & D \\
\hline & BIFACES & & & & & & & & & D & & & & & & & $\mathbf{x}$ \\
\hline
\end{tabular}


Table 3

Comparison of lithic techno-complexes (LTC) with raw material provenances as well as the sites and levels studied. See Table 1 for the colour legend.

SITE

\begin{tabular}{|l|c|}
\hline Combe-Grenal c.38 \\
Combe-Grenal c.36 \\
Combe-Grenal c.35* \\
RdM c.I \\
RdM c.II \\
RdM c.IV \\
RdM c.V \\
RdM c.VI \\
RdM c.VII \\
LeVALLOIS Moustier c.G1/G2 (1)* \\
La Ferrassie c.4 (1) \\
Pech de l'Azé IV c.8 \\
Pech de I'Azé IV c.7 \\
Pech de l'Azé IV c.6 \\
Pech de l'Azé IV c.5 \\
La Plane (1)*
\end{tabular}

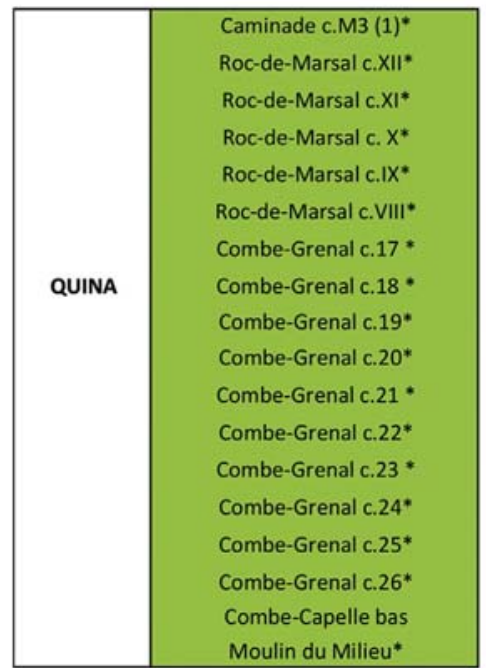

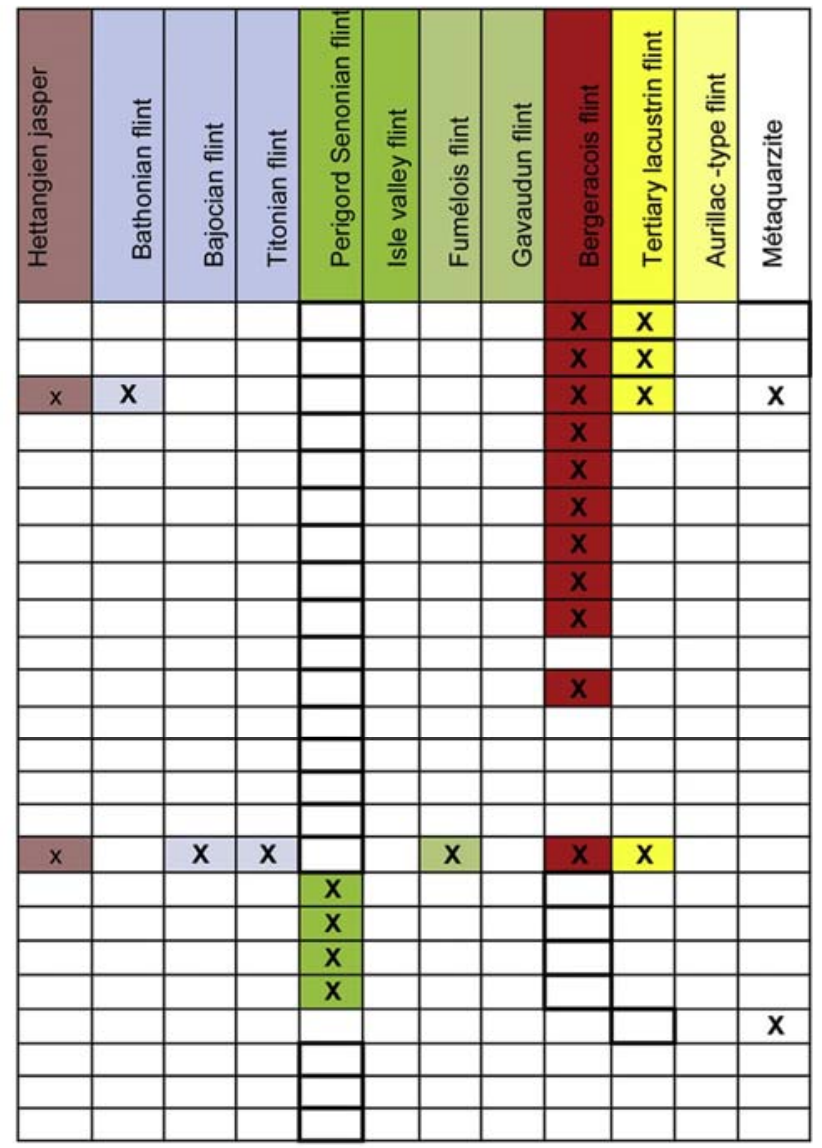

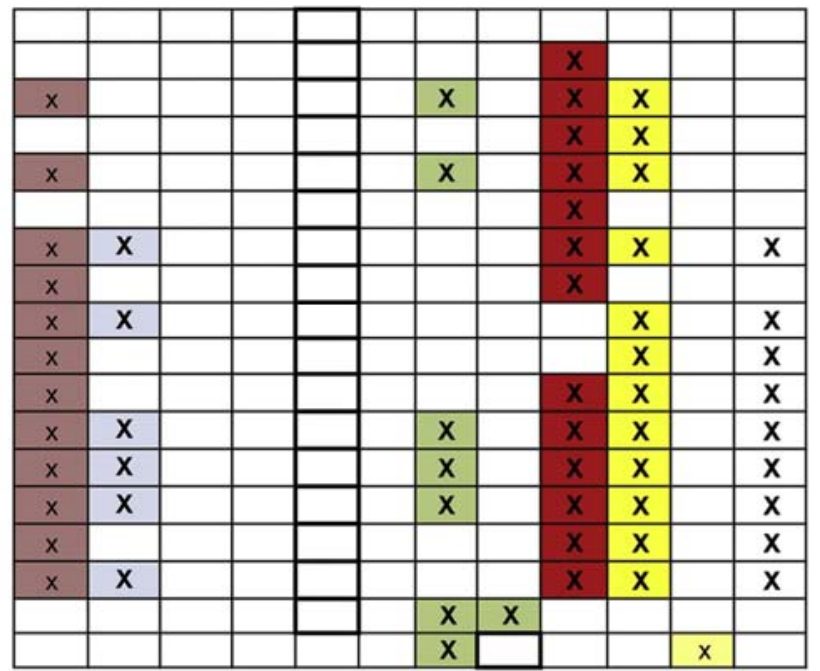



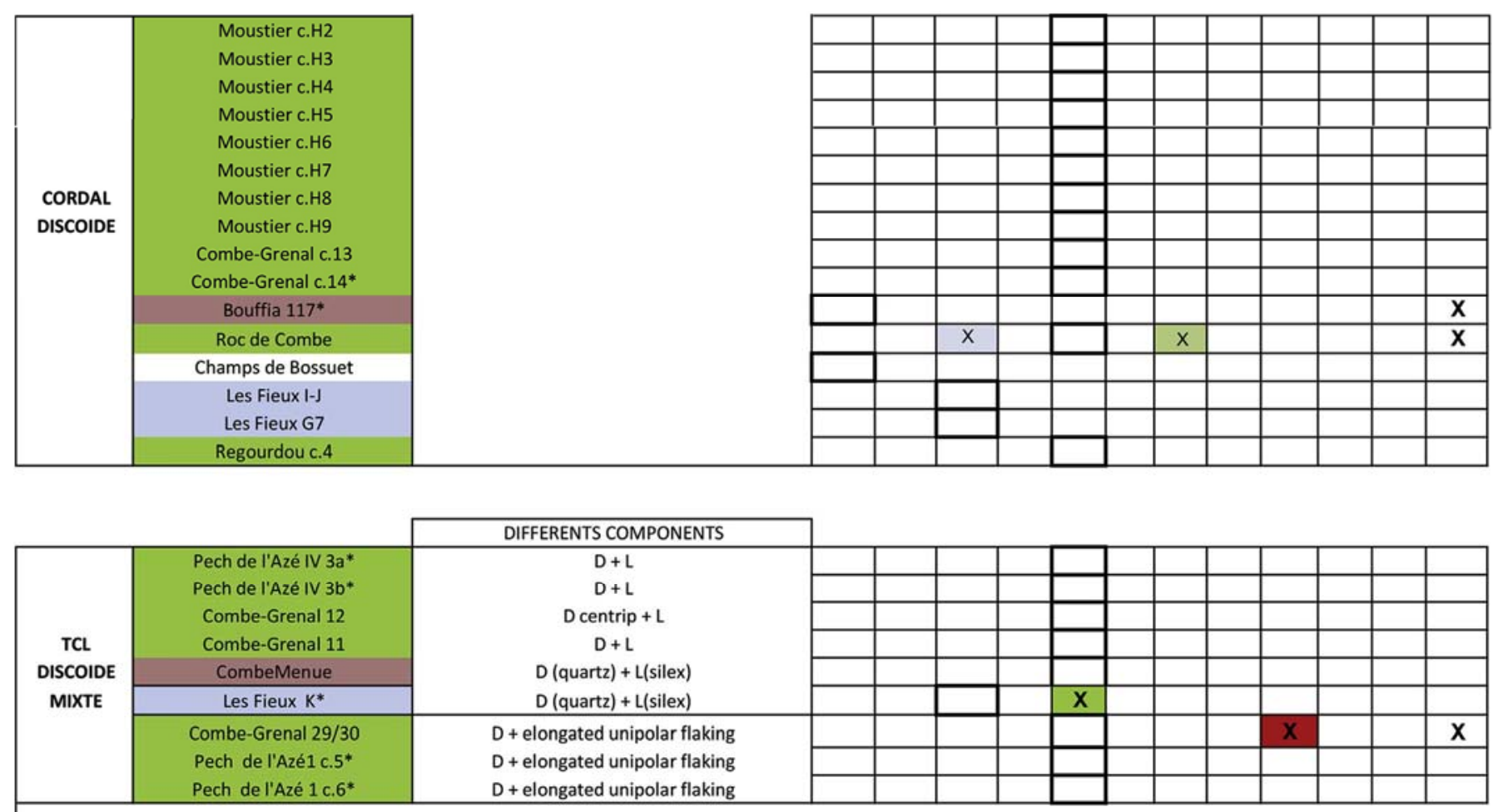

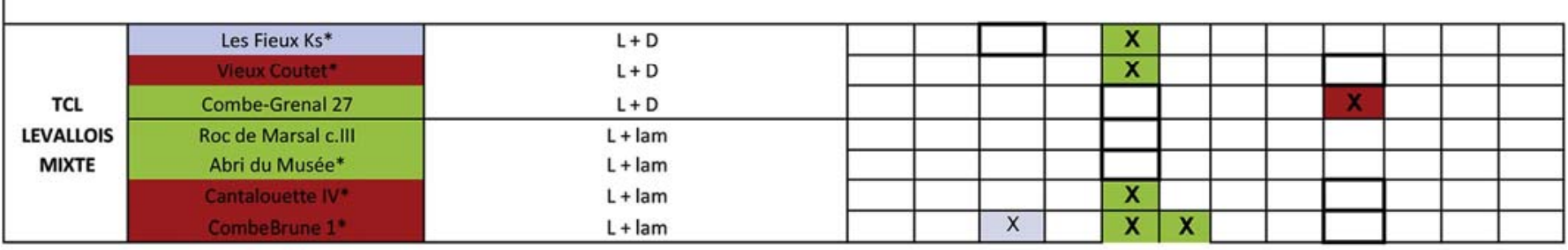

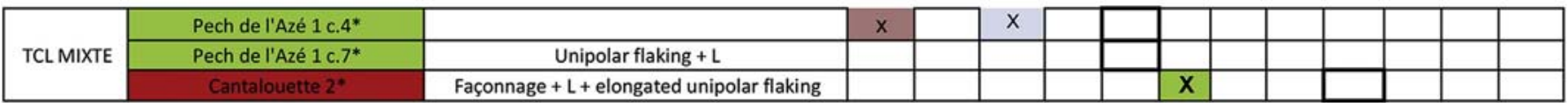

Table 4

Distribution of bifaces in Bergeracois and Perigodian Senonian flint according to the different LZ.

\begin{tabular}{lllll}
\hline Raw material & Dropt Valley & Quercy & Brive Basin & Other Haut-Agenais Lacustrine zones \\
\hline Bergeracois flint & $30 \%$ & - & - & $0.1 \%$ \\
Senonian flint & $10 \%$ & $90 \%$ & $95 \%$ & 0.3 \\
& $\mathrm{~N}=358$ & $\mathrm{~N}=217$ & $\mathrm{~N}=132$ & $\mathrm{~N}=527$ \\
\hline
\end{tabular}

Brantôme, where Mousterian sites are numerous but more often than not excavated early on and under-studied in terms of technology and raw materials. Given the fact that the majority of material from this region derives from old and heavily biased collections, we have excluded sites from this area, retaining the Isle Valley as the northern limit of the study area.

4.1. Neandertal territories and the techno-economic approach: state of the question

Research over the last 20 years has produced evidence of raw material transfers that, at least regionally, appear as general behavioural patterns (Turq, 2000, 2003). Raw materials were almost exclusively (95-100\%) procured from local sources independent of their available in the vicinity of the site. Groups adapted their technologies to the immediately available raw materials regardless their quality or abundance. This is the case, for example, at Corbiac and virtually all the other Mousterian sites in the Bergerac region in close proximity to high-quality flint, as well as Moulin du Milieu in the Haut Agenais, where Gavaudun flint was almost exclusively used. In the Périgord, the same pattern is evident at Roc de Marsal in the use of averagequality, medium-sized alteritic flint and flint from the alluvia of the V'éere River. In both the Quercy (Les Fieux, Mas Viel, Pradayrol) and at La Chapelle-aux-Saints in the Correze, locally available metaquartzites are best represented followed by much smaller quantities of jaspers at the latter. The preferential use of local metaquartzites is equally observable despite flint sources being immediately available less than $5 \mathrm{~km}$ from the site, as at Las Planes and La Pronquiere in the Lot Valley.

The use of the most easily accessible raw materials holds true for all assemblages regardless of the lithic techno-complex, apart from 
Discoid exclusive one. Moreover, these assemblages share more similarities between them then they do with layers from neighbouring sites (e.g. Combe Grenal, Turq, 1992a,b; Vaufrey, Geneste, 1985, 1988a,b). This preference for local resources is evident for all the northern Aquitaine LZ, a pattern that becomes less strict with the emergence of the Upper Palaeolithic (Jaubert and Barbaza, 2005).

In all the studied sites, raw material transfers do not exceed $80 \mathrm{e} 100 \mathrm{~km}$ as the bird flies (e.g. Combe Brune 1, Bourguignon et al., 2006a,b, 2011a,b; Turq et al., 2014; Pailhés, Jaubert et al., 2001; Mas-Viel, Turq, 1992a,b; Le Moustier, Geneste, 1985), with certain types of objects (Levallois flakes, retouched tools, bifaces) appear- ing more mobile (Geneste, 1985). More recent studies have nuanced this overall pattern, demonstrating that cores in different stages of reduction and cortical flakes were equally transported (Turq, 1992a,b; Bourguignon et al., 2006a,b, 2011a,b; Delagnes et al., 2006).

\subsection{Lithological zones and lithic techno-complexes (LTC)}

We revised 69 assemblages from 23 sites distributed across the different lithological zones in order to trace artefact movements away from their source zone(s) (Table 2 and see also Faivre et al., in press). Overall, the sample includes 58 assemblages assigned to lithic technocomplexes characterised by an exclusive flake production system ( 24 Levallois, 18 Quina, and 16 Discoid) and 19 to mixed techno-complexes. Of these 69 assemblages, 28 also contain evidence for bifacial shaping (10 for the Levallois, 17 for the Quina, and 1 for the Discoid).

\subsubsection{Techno-complexes with strictly local raw materials}

Certain LTC are characterised by raw materials procured less than $5 \mathrm{~km}$ from the site, the majority being cordal Discoid assemblages. Like the other LTC and despite the small territory exploited, a comparison of archaeological with experimental data shows all categories of artefact types typical of the cordal Discoid system to have been both imported (e.g. unreduced or decorticated blocks, still reducible cores and pseudo-Levallois points at Les Fieux (Faivre, 2011)) and exported (e.g. pseudo-Levallois points and cores at Regourdou (this study).

\subsubsection{Techno-complexes with both local and distant raw materials}

Levallois techno-complexes are all found in caves and rock shelters (Combe Grenal and Roc de Marsal, 9 assemblages) and most contain evidence for non-local raw materials to have been transported over approximately $50 \mathrm{~km}$, essentially from the Bergerac region or, in the case of Combe Grenal (layer 35), both this region and the Fumel area. Non-local raw materials were introduced in various forms (unmodified flakes, retouched tools, cores, etc.) and, in certain cases, from sources no more then $15 \mathrm{~km}$ from the site. Patterns of raw material transport for the Quina LTCappear very similar to LTC associated with only immediately available sources $(>5 \mathrm{~km})$ for fourteen assemblages from four different sites. Bergeracois and Fumelois flint can be found in assemblages from the same site, while distant raw materials are absent from others (e.g. layer 20 of Combe Grenal).

\subsection{Mixed lithic-technocomplexes}

The mixed LTC evince longer transport distances, particularly for western sites (La Chapelle-aux-saints, Mas-Viel and Pailhés), where the introduction of Bergeracois flint from sources nearly $100 \mathrm{~km}$ to the east is frequent. However, the homogeneity of these assemblages is still debated. Artefacts most commonly transported over distances of $90 \mathrm{e} 100 \mathrm{~km}$ are connected to bifacial shaping, although retouched flake tools (e.g. a double scraper in Puy d'Issolud-type Bajocian flint at Combe Brune 1) can also be transported over similar distances. In these mixed LTC, nonLevallois blades and unipolar elongated flakes are primarily made on locally available raw materials, apart from a single example of a nonLevallois blade core from Cantalouette IV, Blaser et al., 2012). In the case of mixed TCL with a discoidal element, non-local raw materials may, in fact, be connected to associated assemblage components, Levallois or otherwise.

\section{Discussion}

In the study area, only the cordale Discoid LTC, stands out given the recurrent use of immediately available raw materials $(<5 \mathrm{~km})$. When this LTC is accompanied by evidence for bifacial shaping, it frequently involves pieces introduced from more distant sources. The Quina and Levallois LTC portray identical transport patterns in terms of quantity, diversity, and distances. It is equally interesting to note that the Quina and Levallois LTC lacking a non-local raw material component are commonly associated with temperate fauna, as in layers 1 to 4 of Roc de Marsal dominated by red deer (Guérin et al., 2012). On the other hand, for these same LTC, as transport distances increase and become more diversified they are more often associated with predominantly cold fauna (e.g. Combe Grenal layers 22 and 23; Turq, 1990a).

\subsection{Anticipation of needs}

Data from recent rescue excavations of open-air sites shed important light on the anticipation of needs. The exposure of large surfaces likely representing the entire occupation area has allowed for the systematic testing of refits. Unlike cave and rock shelter sites where the entire occupation is rarely excavated and often suffers post-depositional disturbances at its outer edges, assemblages from open-air contexts are more readily interpretable, as in most cases all of the material associated with an occupation is recovered. Refit analyses, as at Cantalouette II (Bourguignon et al., 2008a,b), have demonstrated the limited number of exported elements to also be highly variable (e.g. cortical flakes, end-products). Similar analyses at Combe Brune 1 (Bourguignon et al., 2006a,b, 2007) and Abri du Musée (Bourguignon et al., 2006a,b) went beyond the simple attribution of material to geological formation. By incorporating the post-genetic evolution of flint (Fernandes, 2012), it was possible to identify the specific type of outcrop (Turq, 2000) and thus certain individual blocks (Bourguignon et al., 2006a,b, 2007).

\subsubsection{Reduction and curation}

Patterns of tool reduction and curation are only observable when objects are transported outside their zone of origin. Identifying different curation strategies for transported materials requires petrographic analysis that includes the small fraction $(<25 \mathrm{~mm})$. This type of approach applied to Bergeracois flint and raw materials from the Périgord region is particularly instructive. In the Bergerac LZ, several previously excavated sites (Toutifaut, Barbas, and Corbiac), as well as all six Mousterian sites excavated in rescue contexts by the INRAP, revealed the same behaviour. The same raw materials (grey and black Senonian flint) and artefact types, namely unretouched flakes, tools and intentionally broken flakes were transported over long distances. When considered against the absence of evidence for resharpening and the fact that tools are seldom transformed into cores, this pattern reflects the limited 'curation' of artefacts that were replaced (personal gear) and or complemented by objects in Bergeracois flint. 


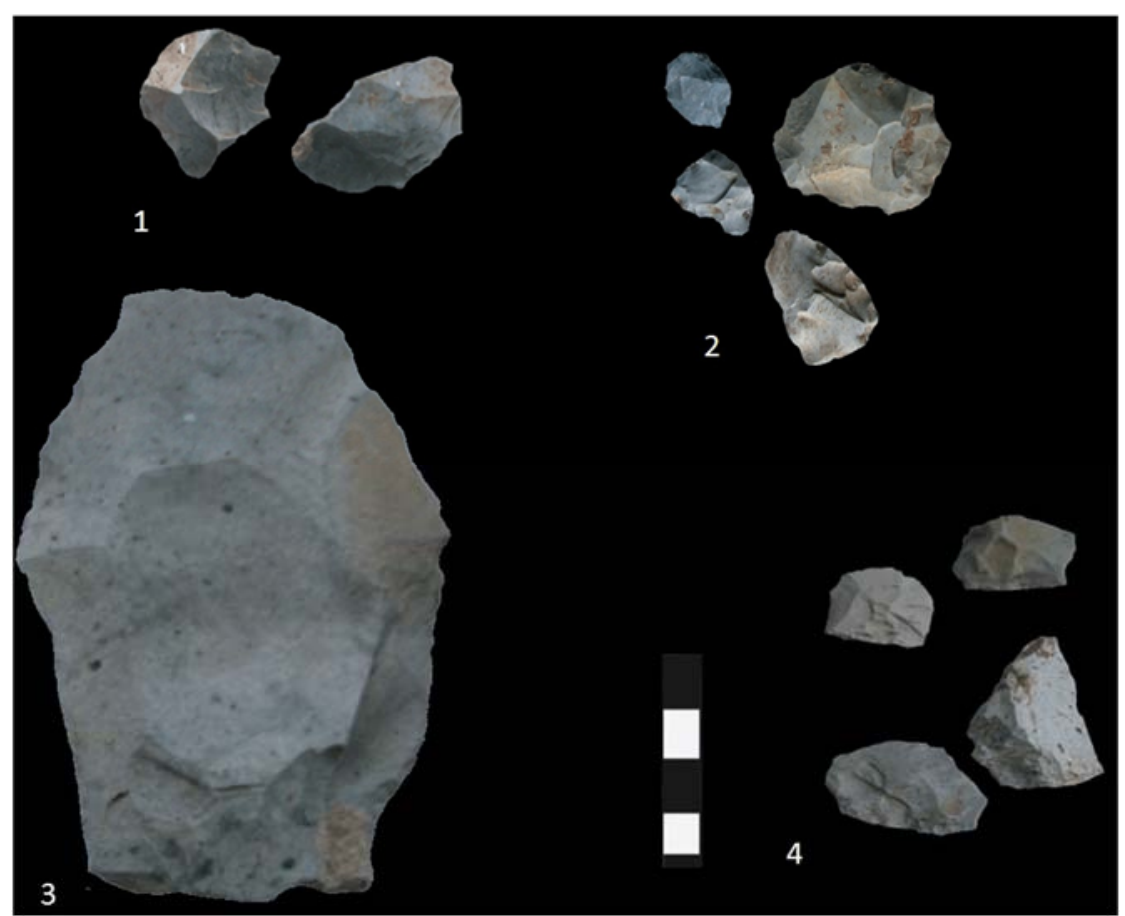

Fig. 4. P'́rigord Senonian flint artefacts found in the Quercy: 1, tool fragments reused as cores; 2, core on flake, 3; Levallois flake; 4 scraper retouch flakes. Photos e Philippe J ugie, Musée national de la Préhistoire.

In the caves and rock shelters of the Perigord, which are often interpreted as habitation sites (Roc de Marsal, Combe-Grenal, Pech de l'Azé I \& IV), imported artefact types also appear relatively similar (unretouched flakes, particularly Levallois products, retouched or bifacial tools), particularly by-products from the resharpening of bifaces or scrapers that were recycled as retouched tools and the occasional intentionally fractured and reused artefact (Fig. 3).

The considerable reduction of tools and the retouching of waste sugges considerable curation. For example, at Mas Viel in the southeastern Jurassic LZ, more than one hundred pieces of Senonian flint and a handful in Bergeracois flint are represented by unmodified flakes, heavily reduced pieces, cores on flake, resharpening by-products and highly fragmented tools often transformed into cores. This pattern reflects a heavily reduced assemblage where pieces are pushed to exhaustion (Fig. 4).

\subsection{A lithological approach to Middle Palaeolithic bifaces}

Certain raw material were seldom used for the production of bifaces, and only in their lithological zone (e.g. Fumelois or Bajocian flint), while other bifacial tools were transported into nearby lithological zones, as can be seen with jasper, Gauvaudun flint and flint from the Isle Valley. Other materials often considered difficult to knap, such as metaquarzites, although rare, are present in all lithological zones apart from the Bergerac region. In terms of raw material transfers, only two raw materials are present in all lithological zones - Bergeracois flint and Senonian flint from the Périgord.

This pattern once again confirms the particular status of the biface in Neandertal mobility strategies and demonstrates three different lithological zones to have seen a particular influx of bifaces: the Dropt Valley, which stands out compared to other Cenozoic lacustrine areas, the Brive Basin, and the Quercy. While more detailed faunal and environmental data is still lacking for better contextualising these patterns, we can nevertheless note the concentration of bifaces around Brive above the confluence of theV'ezère and Corrèze and in the area of Eymet in Dropt Valley at the confluence of several waterways. In the Quercy region, areas rich in biface find-spots have been noted around streamsinks, interpreted as favourable contexts for hunting large herbivores (Champagne and Faivre, 1999) Maynard et al., 2005.

\subsection{Territorial organisation}

The fact that the greatest density of sites with long stratigraphic sequences, as well as those having produced sub-complete Neanderthal skeletons, are all found on Cretaceous formations, suggests the Périgord region to have been a preferential zone of residence (Fig. 5) connected most frequently with the Bergerac region and the Haut-Agenais. Available seasonality data from all large sites in the northeast Aquitaine Basin equally indicates these sites to have been occupied during different seasons (Rendu et al., 2010). Hunter-gatherers exert a daily pressure on their immediate and surrounding environments to such an extent that diminished resource availability may require frequent displacements. In a zone where water, raw materials, and natural shelters are abundant, residential movements are easier. Moreover, the attractiveness of natural shelters varies seasonally as a function of changing wind directions altering ambient temperature and degree of protection.

Relationships between the different lithological zones evince "centrifugal" movements of raw materials away from their place of origin and "centripetal" movement of non-local material towards particular regions. Centrifugal movements concern raw materials introduced to peripheral territories and occasionally beyond, as can be seen with Bergeracois flint and Senonian flints from the Périgord. On the other hand, materials move only between two neighbouring zones, such as Cenozoic lacustrine or Jurassic flints.

Finally, two centrifugal transport patterns, Fumelois and Haut- Agenais flint to the north and Isle Valley flint to the south-east beyond of the Dordogne River valley, crisscross a large portion of the Senonian lithological zone. 


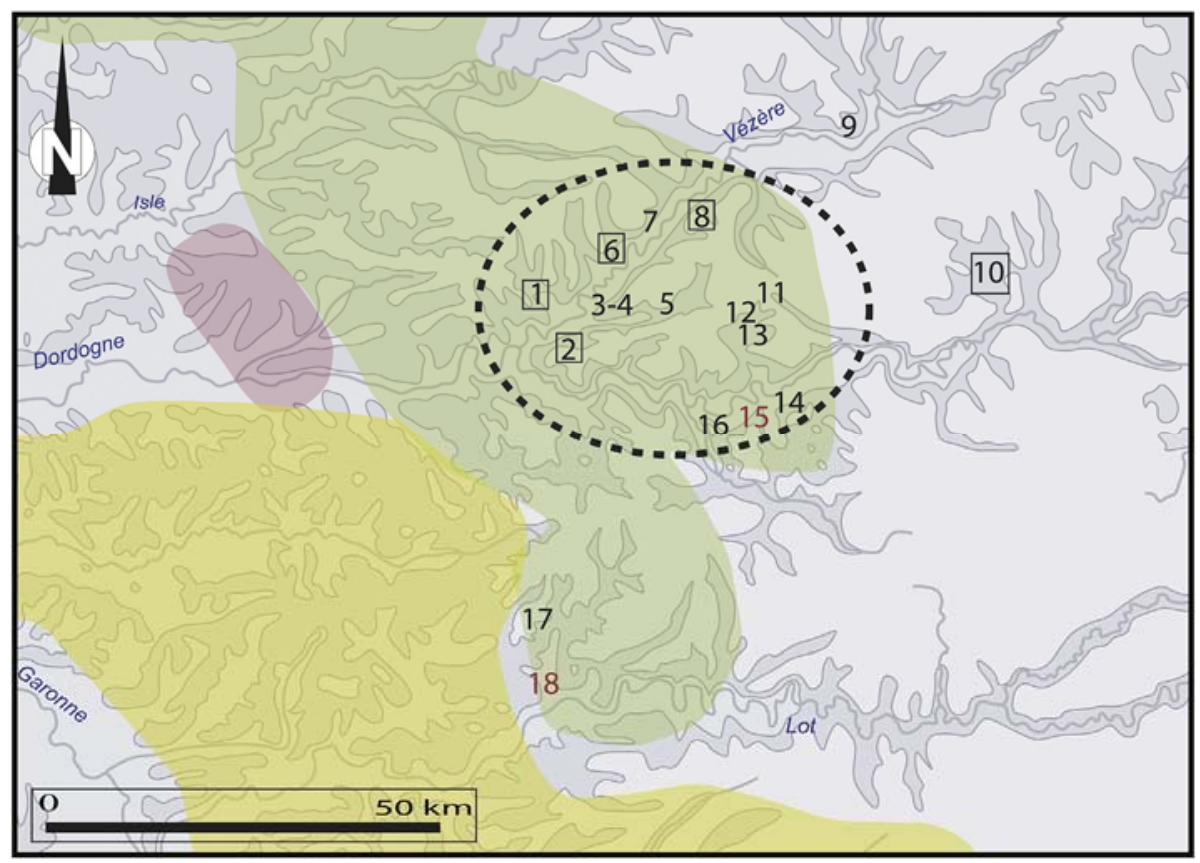

Fig. 5. Distribution of sites with long stratigraphies or sub-complete Neandertal skeletons (black squares) and numerous Neanderthal remains (red squares), preferential zone of residence (dotted line). 1 La Ferrassie, 2 Roc-de-Marsal, 3 et 4 Abri Chadourne et Abri Audi, 5 Laussel, 6 le Moustier, abri supérieur et inferieur, 7 La Rochette, 8 Le Regourdou, 9 ChezPourréChez-Comte, 10 La Chapelle-aux-saints, 11 Pech-de-Bourre, 12 Caminade, 13 les Pech-de-l'Azé 14 La Gane, 15 Combe-Grenal, 16 Vaufrey et Grotte XVI, 17 Moulin-du-Milieu, 18 Monsempron. (For interpretation of the references to colour in this figure legend, the reader is referred to the web version of this article.)

Centripetal movements are more substantial and concern the Bergeracois and Senonian lithological zones that receive raw materials from neighbouring territories as well as further afield. These two zones appear to play a more important role in the organisation of Neanderthal territories, as the others are associated only with materials from peripheral zones. This is the case with the Haut-Agenais where only Bergerac and Senonian flint varieties are found. These observations equally concern elements of different production systems (i.e. Quina, Discoid, Levallois) as well the more frequently transported bifaces (Fig. 6).

Raw materials transported over long distances are also those that derive from the largest outcrops, for example Senonian and Bergeracois flint is available over 4600 and $220 \mathrm{~km}^{2}$, respectively. Connections between different lithological zones correspond either to unidirectional (Cenozoic zones), the Quercy and the Brive Basin or bidirectional movements (Bergerac region, Périgord and Haut

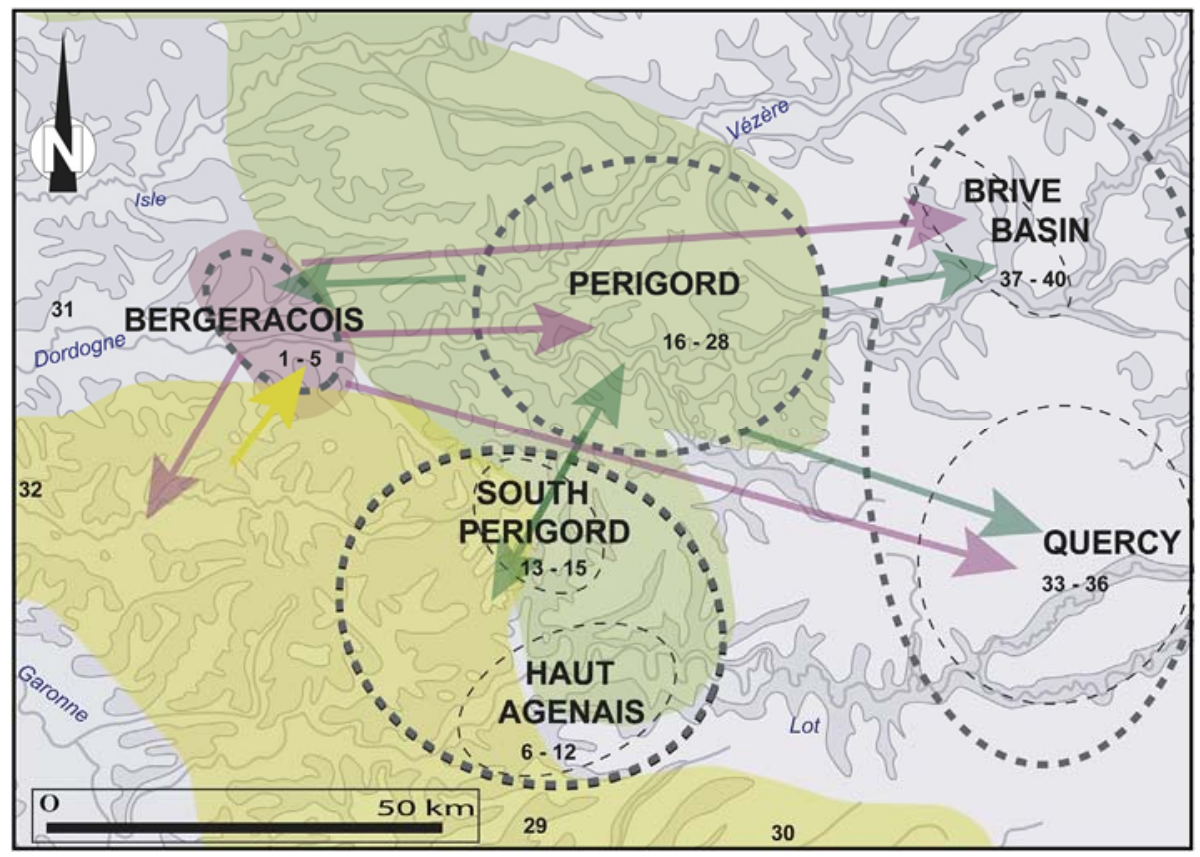

Fig. 6. General relationships between different lithological zones and Neandertal territorial organisation. 


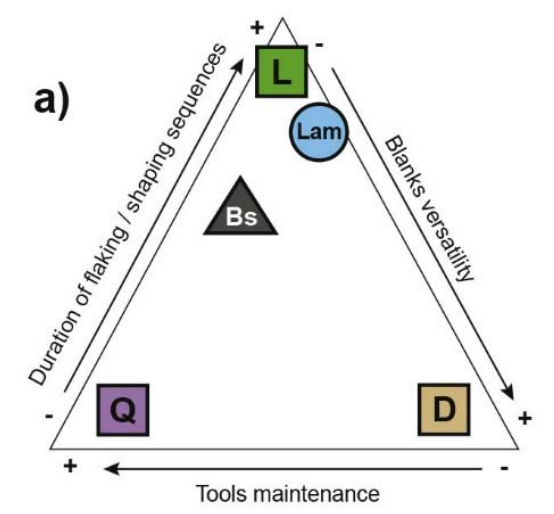

b)

Techno-economic models (Delagnes Rendu 2011):

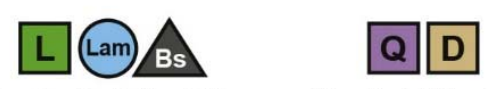

More "residential" mobility More "logistic" mobility

Lithological studies:

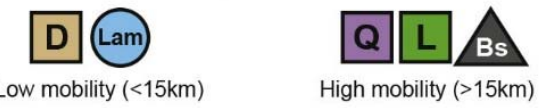

Fig. 7. a, Techno-economic model of lithic production systems (modified after Delagnes and Rendu, 2011); b, comparison of the techno-economic model with raw material transport patterns.

Agenais), with consistent relationships between the Bergerac region, the Haut Agenais and the Périgord. Moreover, this latter region appears to be a central hub for the movement of Neanderthal groups in the region.

\subsection{Mobility patterns}

Evincing relationships between different lithological zones is currently the most secure manner for deducing raw material provisioning zones. However, such relationships reflect the movement of materials and not necessarily the movement of the entire group. In a recent model, Delagnes and Rendu (2010) proposed specific types of mobility patterns associated with different technological systems (i.e. Discoid, Quina, Levallois, MTA) distinguished by their degree of technical investment and standardisation evident in the products. The Discoid and Quina systems are interpreted as reflecting comparable mobility patterns (more logistic) and subsistence strategies based around the high-versatility of both systems combined with extended use-lives and reduced technical investment in the latter. On the other hand, the reduced versatility and resharpening potential of Levallois or blade systems would represent more residential (sensu Binford, 1979) mobility strategies. The curation potential of the bifacial system would occupy an intermediate position between the two mobility patterns. Models of group mobility patterns are currently difficult to test in the Aquitaine Basin due to both the lack of faunal data from many cave and rock shelter sites and the fact that numerous lithic assemblages still require systematic revision. While some of our results may appear to contradict certain aspects of their model, notably the high mobility of Levallois products considered by Delagnes and Rendu as representing a "more residential" system (Fig. 7), they are better seen as complementary. Their model is based on "types" of mobility, while we focus on the transport distances of particular artefacts in the landscape, which help define the actual territories we attempt to model.

\section{Conclusion}

Here we have shown that the provisioning of lithic raw material during the Middle Palaeolithic of the northern Aquitaine Basin essentially involved immediately available raw materials, independent of their distribution in the landscape, and the absence of dedicated forays for their acquisition. Similarly, apart from a few rare contexts associated with the production of bifaces, very few sites correspond to what are broadly termed 'workshops' characterised by a high proportion of artefact export. Raw materials move no more than $40-100 \mathrm{~km}$ and were likely acquired primarily during subsistence rounds, with exchanges between groups or individuals impossible to rule out. The most frequently transported raw materials derive from the largest outcrops, while 'tracer' materials from smaller sources, such as the Fumelois, Gavaudun and Isle Valley flints, are rarely represented except at Moulin du Milieu in the Gavaudun region.

Our most important result is the demonstration of different lithological zones resulting in a preliminary model for the territorial organisation of Neanderthal groups in the northern Aquitaine Basin during MIS 5-3. The middle valleys of the Dordogne, where outcrops of Senonian flints and natural shelters are abundant and water available, functioned as a preferential zone of residence surrounded by an eastern zone around Bergerac with evidence for numerous Middle Palaeolithic sites and the frequent movement of raw materials to and from the region. To the south, the Haut Agenais was only occasionally visited, playing a similar role to the eastern zone in terms of occupation.

The three remaining lithological zones, the Cenozoic lacustrine regions, the Quercy, and the borders of the Massif Central (Limargue and the Brive Basin), are organised around this central hub. Although visited, locally available raw materials were infrequently used and or transported, suggesting areas dedicated to seasonal subsistence activities. These provisioning and transport patterns reveal a sophisticated knowledge of raw material sources and the constant anticipation of future needs. Individuals or mobile groups transported personal gear that both allowed them to meet needs encountered during forays and could be replaced or complemented when the opportunity presented itself. Progressively, as displacements went beyond $40-50 \mathrm{~km}$, raw materials available in neighbouring lithological zones were preferentially exploited (Porraz, 2005). This anticipation of future needs does not necessarily translate as a higher degree of artefact standardisation or the transport of the same artefact types. While it is difficult to determine any fixed rule underlying the choice to transport certain objects, they many appear to share a high degree of curation potential and or reduction.

A fuller understanding of the territorial organisation of hunter-gatherer groups requires the integration of complementary data sets, including paleoenvironmental, subsistence practices and use-wear analysis, as well as new field work and the development of more sophisticated petroarchaeological analyses. Unfortunately, faunal data is only exploitable from a limited number of cave and rock shelter sites, including recent excavations integrating the systematic recovery of the fine fraction (lithics and fauna). More-over, incorporating use-wear analyses and focusing attention on estimating the degree of reduction or curation of both lithic assemblages and particular artefact classes requires integrating experimental work. 
Similarly, advances in understanding the post-genetic alteration of lithic raw materials should begin to help identify the origin of non-cortical pieces, adding more detail and nuance to raw material provisioning strategies. Finally, despite the region's long research history, certain areas, such as the Dronne Valley, have either been ignored or rarely consider and older collections still require revision. The re-excavation of known sites and the discovery of new ones will undoubtedly provide valuable new information for the interpretation of Neanderthal raw material provisioning strategies and territorial organisation. As a final point of reflection, the observations presented here reflect the choices of human groups at a particular moment in time, in a given region and, while certainly providing an interesting case study, they may not be readily exportable to study behaviour in another region with different lithological and ecological conditions.

\section{Acknowledgements}

The authors would like to thank the Service regionale d'arche- ologie (Nathalie Fourment) and thes Musée national de Préhistoire, especially its director J.-J. Cleyet-Merle and the curators or director of museum in Agen, Brive, Cabrerets, Bordeaux, as well as the owners of several private collections. We are also grateful to all the participants of the USIPP B40 - Cleaning up a messy Mousterian: how to describe and interpret Late Middle Palaeolithic chrono- cultural variability in Atlantic Europe (Burgos, September 2014).

This research forms part of the NéMo project financed by a grant from the French National Research Agency program Investissements d'avenir (ANR-10-LABX-52), and BG would like to recognise the French Ministry of Culture and Communication (MCC) for an Allocation de Recherche et Formation that helped fund part of this research. The Région Aquitaine is also thanked for financial support through the program entitled "Chronologie, Préhistoire et Paléoenvironnements" and the CHROQUI program.

\section{References}

Andrefsky Jr., 2009. The analysis of stone tool procurement, production, and maintenance, $17,65-103$

Bernard-Guelle, S., Taylor, A., Rué, M., Fernandes, P., Coudeneau, A., Tallet, P., Hernandez, M., 2014. Les occupations paléolithiques di site de "Bois Clair " à Montguyon (Charente-Maritime). Rapport final d'opération. Paléotime, Service Régional de l'Archéologie d'Aquitaine, p. 625

Bertran, P., Sitzia, L., Banks, W.E., Bateman, M.D., Demars, P.-Y., Hernandez, M., Lenoir, M., Prodeo, F., 2013. The Landes de Gascogne (southwest France): per- iglacial desert and cultural frontier during the Palaeolithic. Journal of Archaeological Science 40 (5), 2274-2285.

Binford, L.-R., 1979. Organization and formation processes: looking at curated technology. Journal of Anthropological Research 35, 255-273

Binford, L.-R., Binford, S.-R., 1969. Stone tools and human behavior. Scientific American $220,70-84$.

Blaser, F., Bourguignon, L., Sellami, F., Rios, J., Vieillevigne, E., Guibert, P., 2012. Un site à

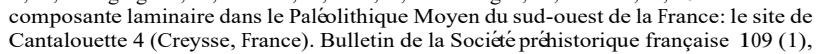
Cantal

Boëda, E., 2005. Paléo-technologie ou anthropologie des Techniques? Arob@se 1, 46-64. www.univ-rouen fr/arobase.

Boëda, E., 2013. Technologique et technologie. Une préhistoire des objets lithiques. Collection Préhistoire au Présent. Archéo-editions.com.

Boëda, E., Geneste, J.-G., Meignen, L., décembre 1990. Identification des chaînes opératoires lithiques du paléolithique ancien et moyen. Paléo 2, 43-80.

Bordes, J.-G., 2002. Les interstratifications Châtelperronien/Aurignacien du Roc de Combe et du Piage (Lot, France): analyse taphonomique des industries lithiques, implications archéologiques (Doctoral dissertation). Université Bordeaux 1.

Bourguignon, L., 1992. Processus opératoire des pièces à coups de tranchets latéraux, dans l'industrie moustérienne de l'Abri du Musée (les Eyzies de Tayac). Paléo 4, 67-87.

Bourguignon, L., 1997. Le Moustérien de type Quina: nouvelle définition d'une entité Paris X-Nanterre.

Bourguignon, L., 2001. Apports de l'expérimentation et de l'analyse techno- morphofonctionnelle à la reconnaissance du processus d'aménagement de la retouche Quina. In: Ortega, I., Frère-Sautot, M.C. (Eds.), Préhistoire et approche expérimentale, sous la In: Ortega, I., Frere-Sautot, M.C. (Eds.), Prehistoire et approche
direction de L. Bourguignon. M. Mergoil, Montignac, pp. 35-66.

Bourguignon, L., Turq, A., Faivre, J.-Ph, 2004. Ramification des chaînes opératoires: Spécificité du Moustérien? Paléo 16,37-48.

Bourguignon, L., Delagnes, A., Meignen, L., 2006a. Systèmes de production lithique, gestion des outillages et territoires au Paléolithique moyen: où se trouve la complexité? In: Astruc, L., Bon, F, Léa, V., Milcent, P.-Y., Philibert, S. (Dirs.), Normes techniques et pratiques sociales. De la simplicité des outillages pré et protohistoriques, XXVIe rencontres internationales d'archéologie et d'histoire d'Antibes, Éditions APDCA, Antibes. pp. 75-86.
Bourguignon, L., Bidart, P., Ortega, I., Turq, A., Detrain, L., Morala, A., 2006b (abstract of communication). Du territoire proche au territoire lointain: differences ou similitudes comportementales à partir des stratégies d'exploitations gîtologi- ques des matières premières lithiques au Paléolithique moyen (l'exemple de Combe Brune 1 et de l'Abri du premieres lithiques au Paleolithique moyen ('exemple de Combe Brune 1 et de l'Abri du Workshop 23 UISPP, 2006, Lisbonne. Aires d'approvisionnement en matières premiëres Workshop 23 UISPP, 2006, Lisbonne. Aires d'approvisionnement en matieres premieres
et aires d'approvisionnement en ressources alimentaires approche intégré des et aires d'approvis
comportements.

Bourguignon, L., Blaser, F., Rios, J., Pradet, L., Sellami, F., Guibert, P., 2008a. L'occu- pation moustérienne de la Doline de Cantalouette II: Spécificités tech- nologiques et économiques premiers résultats d'une analyse intégrée. In: Jaubert, J., Bordes, J.-G., Ortega organisateurs, I. (Eds.), Les sociétés du Paléolithique dans un grand Sud-ouest: nouveaux gisements, nouveaux résultats, nouvelles méthodes, Séances de la SPF, 24-25 novembre 2006, Bordeaux, Mémoires. SPF, vol. 47, pp. 133-150.

Bourguignon, L., Turq, A., Faivre, J.Ph., 2008b (abstract of communication). Complémentarité et/ou supplementarite entre les occupations de plein air et en contexte karstique du Paléolithique moyen récent en Aquitaine septentrionale: apports des données récentes. In: Depaepe, P., Goval, E., Koehler, H., Locht, J-L. (Organisées par), Journées SPF, 28 et 29 Mars 2008 «Les plaines du Nord-Ouest: carrefour de l'Europe au Paléolithique moyen?.

Bourguignon, L., Brenet, M., Folgado, M., Ortega, I., 2011a. Aproximación tecno- económica del debitage Discoide de puntas pseudo-Levallois: El aporte de la experimentación. In: Morgado Rodríguez, A., Baena Preysler, J. (Eds.), La

investigacion experimental aplicada a la arqueologia. Galindo, SL (Ronda, Ma- laga), pp. 53-59.

Bourguignon, L., Bidart, P., Turq, A., Rios, J., Ortega, I., 2011b. Chapitre IV Etudes des vestiges lithiques. In: Bidart, P., Bourguignon, L., Ortega, I., Sellami, F., Rios, J., Guibert, P., Turq, A. (Eds.), Le Gisement Moustérien de Tradition Acheuléenne de Combe Brune 1, Déviation nord de Bergerac. Inrap, pp. 47-120. Rapport Final d'Opération.

Bourguignon, L., Turq, A., Fauquignon, J., 2013. Lascas de puesta en funcionamiento, de reacondicionamiento y de reciclado de las raederas Quina: Estimación e interpretación tecno-económica. In: Experimentación en arqueología. Estudio y difusión. Serrie Monográfica del MAC-Girona 25-1, Girona, pp. 229-235.

Bruxelles, L., Jarry, M., 2011. Climatic conditions, settlement patterns and cultures in the Paleolithic: the example of Garonne Valley (Southwest France). Journal of Human Evolution 61, 538-548.

Bruxelles, L., Chalard, P., Ciszak, R., Ducasse, S., Guillermin, P., 2010. Geo- archaeological prospecting and palaeolithic exploitation strategies of the bajocien flints in Haut-Quercy, France. In: Brewer-Laporta, M., Burke, A., Field, D. (Eds.), Ancient Mines and Quarries: a Trans-atlantic Perspective. Oxbow Books Limited, Oxford, pp. 1-12.

Cassedoubat, M., Platel, J.-P., 1976. Le Turonien de la bordure septentrionale du Bassin Aquitain. Etude sédimentologique et paléogéographique (Doctoral dissertation). Université Bordeaux III.

Caux, S., 2015. Du territoire d'approvisionnement au territoire culturel Pétroarchéologie et techno-économie du silex Grain de mil durant l'Aurignacien dans le Sud-ouest de la France (Doctoral dissertation). Université de Bordeaux I.

Cavaillé, A.,1978. In: Renault, Ph., et al. (Eds.), Géologie du Quercy. Cahors: éd. QuercyRecherche,Les suppléments de Quercy-Recherche: Série Etudes et Travaux, vol. 4, p. 111, ill.

Chadelle, J.-P., 1983. Technologie et utilisation du silex au Périgordien supérieur: l'exemple de la couche VII du Flageolet I. In: Toulouse, Ecole des Hautes études en Sciences sociales (mémoire).

Chalard, P., 1996. Les gîtes à silex du Quercy. rapport de synthèse. In: Chalard, P., Briois, F., Lacombe, S., Servelle, Ch., Simonnet, R. (Eds.), Lithothèque des mat- ières premiëres siliceuses. In: Région Midi-Pyrénées (Ed.), Projet Collectif de Recherche, pp. 15-55. Toulouse.

Chalard, P., 1999. Les gîtes à silex du Quercy. In: Briois, F. (Ed.), Lithothèque des matières premiêres siliceuses: Région Midi-Pyrénés, Toulouse, Projet Collectif de Recherche, rapport de synthèse, pp. 162-164, 20-31.

Champagne, F., Faivre, J.-Ph, 1999. Deux séries lithiques récoltées en surface à Gary et Grèzes, Commune de Miers, Lot. Bulletin de Préhistoire du Sud-ouest 6 (fasc 1), 13-32.

Charly, N., 1993. Ressources en matériaux siliceux du Cantal: un exemple d'exploitation sur le site de Cors au magdalénien final. In: Mémoire de D.E.A.. Université de Paris 1.

Combaz, A., 1966. Recherches de microfossiles organiques dans les sables et grès du Périgord. In: Compte Rendu D'examen, vol. 189. Exploration, Laboratoire Cen- tral, Bordeaux C.F.P.

Coulonges, L., de Sonneville-Bordes, D., 1953. Le Paléolithique du Plateau Cabrol à Saint-Frontsur-Lémance (Lot-et-Garonne). Bulletin de la Sociéte préhistorique française 50 (fasc. 56), 333-337.

Cubaynes, R., Faure, Ph., Hantspergue, P., Péliussié, Th., Rey, J., 1989. Stratigraphie séquentielle sur la plate-forme carbonatée du Quercy. pré print d'une note publiée par. Géologie de la France 114 fasc. 3 .

Dawson, M.-C., Bernard-Guelle, S., Rué, M., Fernandes, P., 2012. L'atelier de taille moustérien du Chêne Vert à Dirac (Charente): nouvelles données sur l'exploi- tation des gîtes de silex au Paléolithique moyen. Revue Paléo 23, 55-84.

Delagnes, A., 2010. Systèmes techniques, subsistance et mobilité au Paléolithique moyen interactions et implications diachroniques. HDR, Université de Bordeaux I.

Delagnes, A., Rendu, W., 2011. Shifts in Neandertal mobility, technology and sub- sistence strategies in western France. Journal of Archaeological Science 38, 1771-1783.

Delagnes, A., Feblot-Augustins, J., Meignen, L., Park, S.-J., 2006. L'exploitation des silex au Panes, A., Feblot-Augustins, J., Meignen, L., Park, S.-J., 2006. Lexploitation des silex au
Paleolithique moyen dans le bassin de la Charente: Qu'est-ce qui cir- cule, comment...et pourquoi? In: Bulletin de l'Association des Archéologues de Poitou-Charentes, vol. 35, pp. pourqu

Delagnes, A., Jaubert, J., Meignen, L., 2007. Les technocomplexes du paléolithique moyen en Europe occidentale dans leur cadre diachronique et géographique. In
.

Vandermeersch, B., Maureille, B. (Eds.), Les Neandertaliens. Biologie et Cultures. Editions du Comité des Travaux Historiques et Scientifiques, Paris, pp. 213-229

Demars, P.-Y., 1980. Les matières premières siliceuses utilisées au Paléolithique supérieur dans le bassin de Brive (Doctoral dissertation Bordeaux).

Faivre, J.-P., 2011. Organisation techno-économique des systèmes de production dans le Paléolithique moyen récent du nord-est aquitain. BAR, Oxford.

Faivre, J.-Ph., Gravina, B., Bourguignon, L., Discamps, E., Turq, A., 2016. Late Middle Palaeolithic lithic technocomplexes (MIS 5-3) in the northeastern Aquitaine Basin: advances and challenges. Quaternary International (in press), $\mathrm{http} / / \mathrm{dx}$. doi.org/10.1016/j.quaint.2016.02.060. 
Féblot-Augustins, J., Park, S.J., Delagnes, A., 2005. Lithothèque du bassin de la Charente http://www.alienor.org/articles/lithotheque.

Fóblot-Augustions, J., Park, S.-J., 2009. Histoires de silex. Prospections géologiques dans le bassin de la Charente et caractérisations pétrographiques. In: Bulletin de l'Association des Archéologues de Poitou-Charentes, vol. 39.

Fernandes, P., 2012. Itinéraires et Transformation du silex: une pétroarchéologie refondée, application au Paléolithique moyen (Doctoral dissertation Bordeaux).

Fernandes, P., Morala, A., Schmidt, P., Séronie-Vivien, M.-R., Turq, A., 2012. Le silex de Bergeracois: état de la question. In: Bertran, P., Lenoble, A. (Eds.), Quaternaire continentale d'Aquitaine: un point sur les travaux récents. Excursion AFEQ-ASF 2012 INRAP/Universite de Bordeaux 1, Bordeaux

Fouéré P., 1994. Les industries en silex entre Néolithique moyen et Campaniforme dans le nord du Bassin Aquitain (Doctoral dissertation Bordeaux).

Geneste, J.-M., 1985. Analyse lithique d'industries moustériennes du Périgord: une approche technologique du comportement des groupes humains du paléolithique moyen (Doctoral dissertation Bordeaux)

Geneste, J.-M., 1988a. Système d'approvisionnement en matières premières au Paléolithique moyen et Paléolithique supérieur en Aquitaine. In: Otte, M. (Ed.), L'Homme de Néandertal, La Mutation, vol. 8. ERAUL 35, Liège, pp. 61-70.

Geneste, J.-M. (1988b). Les industries de la grotte Vaufrey: technologie du débitage, économie et circulation de la matière première lithique. In: La grotte Vaufrey: Paléoenvironnement, Chronologie, Activités Humaines, Rigaud, J.-Ph. (Dir.), Mémoires de la Société Préhistorique Française, t. XIX, pp. 441-517.

Guerin, G., Discamps, E., Lahaye, C., Mercier, N., Guibert, P., Turq, A., Dibble, H., McPherron, S., Sandgathe, D., Goldberg, P., Jain, M., Thomsen, K., Patou- Mathis, M., Castel, J.-C., Soulier, M.-C., 2012. Multi-method (TL and OSL), multi- material (quart: and flint) dating of the Mousterian site of the Roc de Marsal (Dordogne, France) correlating Neanderthals occupations with the climatic variability of MIS 5-3.

Guibert, P., Bechtel, F., Bourguignon, L., Brenet, M., Couchoud, I., Delagnes, A., Delpech, F., Detrain, L., Duttine, M., Folgado, M., Jaubert, J., Lahaye, Ch., Lenoir, M., Maureille, B. Texier, J.-P., Turq, A., Vieillevigne, E., Villeneuve, G., 2008. Une base de données pour la chronologie du Paléolithique moyen dans le Sud-Ouest de la France. In: Jaubert, J. Bordes, J.-G., Ortega, I. (Eds.), Les sociétés du Paléolithique du grand Sud-Ouest de la France: nouveaux gisements, nouveaux résultats, nouvelles méthodes, Mémoires de la Sociétépréhistorique française, vol. XLVII. Société préhistorique française, Paris, pp. 1940.

Jaubert, J., 2011. Les archéo-séquences du Paléolithique moyen du sud-ouest de la France: quel bilan un quart de sièle apres François Bordes? In: Delpech, F., Jaubert, J. (Eds.), François Bordes et la Prehistoire: Colloque international François Bordes, Bordeaux, 22-23 Avril 2009. Editions du Comité des Travaux Historiques et Scientifiques, Paris, pp. 235-253.

Jaubert, J., et al., 2001. Un site moustérien de type Quina dans la vallée du Célé (Pailhès à Espagnac-Sainte-Eulalie, Lot). Gallia-Préhistoire 43, 1-99.

Kuhn, S.-L., 1992. On planning and curated technologies in the Middle Paleolithic. Journal of Anthropological Research 48, 185-213.

Kuhn, S.-L., 1995. Mousterian Lithic Technology. An Ecological Perspective. Prince- ton University Press, Princeton.

Landesque, (Abbé), 1887. Excursion à la station préhistorique de Combe-Capelle. Bulletin de la Société géologique de France XV.

Larick, R.-R., 1983. The Circulation of Solutrean Foliate Point Cherts: Residential Mobility in the Perigord (Unpublished Ph. D. Dissertation). Dept. of Anthro- pology, Binghamton.

Le Brun-Ricalens, F., 1988. Contribution àl'étude du Paléolithique du pays des Serres du Bas-Quercy et de l'Agenais entre les vallées du Lot et de la Garonne. In: Mémoire de D.E.A. Université de Toulouse II Le Mirail.

Le Tensorer, J.-M., 1979. Recherches sur le Quaternaire en Lot-et-Garonne: stratigraphie, paléoclimatologie et préhistoire paléolithique (Doctoral dissertation Bordeaux I).

Lorblanchet, M., 1969. Les bifaces de la Vercantière (Saint-Michel-de-Bannières) et de Duravel (Lot) et les débuts de l'occupation humaine en Haut-Quercy. In Bulletin de la Société des études du Lot, t. XC, fasc. 1, pp. 23-39.

Monméjean, E., Bordes, F., de Sonneville-Bordes, D., 1964. Le Périgordien supérieur à burins de Noailles du Roc de Gavaudun (Lot-et-Garonne). L'Anthropologie 68 (3-4), 253-316.

Morala, A., 1980. Observations sur le Périgordien, l'Aurignacien et leurs matières premières lithiques en Haut-Agenais. In: Toulouse, école des Hautes études en sciences sociales, p. 191.

Morala, A., 1983. A propos des matières premières lithiques en Haut-Agenais. Bulletin de le Société préhistorique française 80 (6), 169.

Muratet, B., 1983. Geodynamique du paleogene continental en Quercy-Rouergue: analyse de la sedimentation polycyclique des bassins d'Asprieres (Aveyron), Maurs (Cantal) et Varen (Tarn-et-Garonne) (Doctoral dissertation). L'Université Pau Sabatier

Park, S., 2007. Systèmes of production lithique et circulation des matières première au Paléolithique moyen récent et final (Doctoral dissertation). Université Paris XNanterre.

Pasty, J.-F., Surmely, F., Tzortzis, S., 1999. Contríbution à un inventaire des ressources en silex. Le département du Cantal (Massif central, France). Bulletin de la Société Préhistorique Française 96 (1), 7-13.

Porraz, G., 2005. En marge du milieu alpin - Dynamiques de formation des ensembles lithiques et modes d'occupation des territoires au Paléolithique moyen (Doctoral dissertation Aix en Provence)

Rey-Solé, M., Mangado, X., Delage, C., 2014. New data about Cenomanian and Turonian chert from the Charente basin (France). Journal of Lithic Studies 1 (1), 227-238.

Rigaud, J.-Ph., 1982. Le Paléolithique en Périgord: les données du Sud-Ouest sarladais et leurs implications (Doctoral dissertation Bordeaux)

Roussel, P., 1972. Prospections de surface dans la région de Gourdon. In: Bulletin de la Société des études du Lot, t. XCIII, fasc. 2, pp. 155-161.

Séronie-Vivien, M., M.-R., 1987. Les silex du Mésozoïque nord-aquitain: approche géologique de l'étude du silex pour servir à la recherche. In: Bulletin de la Sociéte Linéenne de Bordeaux suppl. au t. XV, $135 \mathrm{p}$.

Simon-Coinçon, R., 1989. Le rôle des paleoalterations et des paléoformes dans les socles: l'exemple du Rouergue (Massif Central français). In: École des Mines de Paris, Mémoires des sciences de la terre, vol. 9.

Sitzia, L., 2014. Chronostratigraphie et distribution spatiale des dépôts éoliens quaternaires du bassin aquitain (Doctoral dissertation Bordeaux I). de Sonneville-Bordes, D., 1953. Le Paléolithique supérieur du Plateau Baillard à Gavaudun (Lot-et-Garonne). Bulletin de la Société préhistorique française 50 (5-6), 356-364.

Soressi, M., 2002. Le Moustérien de tradition acheuléenne du Sud-ouest de la France. Discussion sur la signification du faciès à partir de l'étude comparée de quatre sites: Pech de l'Azé I, le Moustier, La Rochette et la Grotte XVI (Doctoral dissertation Bordeaux)

Turq, A., 1977. Le complexe d'habitat préhistorique du Plateau Cabrol. Bulletin de la Société préhistorique française $74,489-504$. études et Travaux, fasc. 2 .

Turq, A., 1988. Origine des roches siliceuses. In: Dubreuilh, J., et al. (Eds.), Notice explicative de la feuille Belvès à 1/50 000. Ed. du B.R.G.M, Orléans, pp. 29-34.

Turq, A., 1990a. Exploitation des matières premières dans le Moustérien entre Dordogne et Lot. In: Cahiers du Quaternaire, ${ }^{\circ} 17$. Le silex de sa genèse à l'outil.

Actes du Ve Colloque international sur le silex, pp. 415-427.

Turq, A., 1990b. Exploitation du milieu minéral: technologie, économie et circula- tion des silex. In: Jaubert, J., Lorblanchet, M., Laville, H., Slott-Moller, R., Turq, A.,

Brugal, J.-Ph. (Eds.), Les chasseurs d'Aurochs de La Borde. Un site du Paléolithique moyen (Livernon, Lot), Documents d'Archéologie Française, vol.27 Ed. Maison des sciences de l'Homme, Paris, pp. 103-115.

Turq, A., 1992a. Raw material and technological studies of the Quina Mousterian in Perigord. In: Dibble, Harrold L., Mellars, Paul (Eds.), The Middle Paleolithic: Adaptation, Behavior, and Variability, University Museum Monograph 78, University Museum Symposium Series, vol. IV. The University Museum University of Pennsylvania, pp. 75-85.

Turq, A., 1992b. Le Paléolithique inférieur et moyen entre les vallées de la Dordogne et du Lot (Doctoral dissertation Bordeaux).

Turq, A., 2000. Le Paléolithique inférieur et moyen entre les vallées de la Dordogne et du Lot. Paléo 456 supplément $\mathrm{n}^{\circ} 2$, avril 2000.

Turq, A., 2003. De la matière première lithique brute à la mise au jour de l'objet archéologique: propositions pour une meilleure exploitation du potentiel informatif du materiel lithique illustrées par quelques exemples du Paléolithique aquitain (dissertation of Habilitation à Diriger des Recherches). Université de Perpignan.

Turq, A., Dibble, H.L., Goldberg, P., McPherron, S.P., Sandgathe, D., Jones, H., Maddison, K., Maureille, B., Mentzer, S., Rink, J., Steenhuyse, A., 2011. Les fouilles récentes du Pech de l'Azé(Dordogne). Gallia Préhistoire 53, 1-58. Turq, A., Morala, A., Séronie-Vivien, M.-R., 2013a. Inventaire des silicifications du Quercy, de ses marges et des marqueurs lithologiques du nord-est aquitain: synthèse des données. In: Jarry, M., Brugal, J.-Ph., in Ferrier, C. (Dirs.), Modalité d'occupation et d'exploitation des milieux dans le Sud-Ouest de la France: l'exemple du Quercy, Paléo, supplément $n^{\circ}$ 4. pp. 59-180.

Turq, A., Roebroeks, W., Bourguignon, L., Faivre, J.-P., 2013b. The fragmented char- acter of Middle Palaeolithic stone tool technology. Journal of Human Evolution 65, 641-655, 1-15.

Vergne, A., 1929. Les stations préhistoriques de Gavaudun: l'Abri Peyrony. Revue de l'Agenais $1929,137-152$

Vieillevigne, E., Bourguignon, L., Ortega, I., Guibert, P., 2008. Analyse croisée des données chronologiques et des industries lithiques dans le grand sud-ouest de la France (OIS 10 à 3). Paleo 20, 145-165.

Weyns, W., 1972. Contribution à l'étude hydrogéologique des assises crétacés dans le Lot et Garonne (doctoral dissertation) 
